\title{
Making Embedded Knowledge Transparent: How the V-Dem Dataset Opens New Vistas in Civil Society Research
}

In this article we discuss the Varieties of Democracy (V-Dem) Civil Society data, a new and unparalleled resource that captures multiple dimensions of civil society across over 170 states since 1900. The value-added of the V-Dem civil society data, that it encompasses diverse indicators over an unprecedented geographic and temporal scope, is possible because it has taken a store of detailed and rich human knowledge -- the embedded knowledge of country experts -- and transformed it into comparable time-series cross-sectional data that facilitates new forms of descriptive and theoretical inference.

Here we make prominent use of three new variables that allow us to gauge civil society strength and participation. However, the larger dataset allows researchers to track a range of new variables for many other aspects of civil society that heretofore, despite their relevance to important theoretical questions, have been difficult to gauge. These include concepts such as the degree to which decisionmakers consult with civil society actors, the presence and nature of anti-system movements, state harassment and regulation of civil society organizations, the predominant organizational pattern of civil society organizations, and the degree to which civil society excludes both female and religious actors. ${ }^{1}$

We begin with a discussion of the importance of civil society as a relatively new concept in comparative politics and the difficulty of testing general propositions about it due to the existing data environment. We then discuss the data generally and highlight two mid-range indices developed by $\mathrm{V}$ Dem, the Core Civil Society Index (CCSI) and the Civil Society Participation Index (CSPI). With these basics established, we then report on a series of validity tests for the CCSI which demonstrates the level of dense historical nuance that the V-Dem data embodies, and then demonstrates the utility of the data by revisiting the debate on the strength of postcommunist civil society. The V-Dem data shows that civil 
society in the region exhibits a great deal of variation, that it is neither universally strong nor weak, and that greater caution is warranted in generalizing about civil society in the postcommunist region.

\section{The Emergence of Civil Society as a Key Concept in Comparative Politics}

Civil society has been an important concept in both political theory and the study of regimes and regime change in modern political science. It played a critical role in the conceptualization of modern society in the political thought of the Scottish Enlightenment ${ }^{2}$ and German Idealism. ${ }^{3}$ It has also received a great deal of attention in contemporary critical theory. ${ }^{4}$ However, in many regards the notion of civil society that we employ in political science today has two parents, the Italian Marxist Antonio Gramsci ${ }^{5}$ and the French aristocrat Alexis de Tocqueville. ${ }^{6}$ From Gramsci we continue to think of civil society as a realm of contestation, where organized social actors challenge the power of the state and other social forces. From Tocqueville we draw the notion that civil society is the integument of democracy. Instead of stoking reactionary nightmares of democracy as mob rule, Tocqueville explored how an engaged and organized citizenry enables more egalitarian, mass-based forms of rule.

In modern comparative politics civil society reemerged as a central concept of analysis in the 1980 s to describe the reemergence of protest movements and underground organizations under authoritarian regimes. This analysis is neo-Gramscian in nature, in that it sees civil society as an emergent realm of contestation with dictatorship. What was novel about this approach was that civil society was posited to coexist with authoritarian regimes and that this held the potential to liberalize, if not democratize them. Among the earliest and most influential in this regard was Alfred Stepan who observed such development first-hand in Brazil in its resistance to military dictatorship. ${ }^{7}$ In Eastern Europe, Andrew Arato made similar observations on the emergence of new oppositional social actors as the impetus for change in state socialist regimes. ${ }^{8}$ This observation was significant because the essence of the state-socialist project was the abolition of civil society. ${ }^{9}$ 
With the third wave of democratization this neo-Gramscian notion of a contentious civil society was integrated into influential actor-centered process models of democratic transition. O'Donnell and Schmitter refer to the response of social actors to new opportunities opened up by liberalization as "the exploding layers of society." ${ }^{10}$ Such mobilization is a decisive factor in the extension of liberalization into democratic transition. Przeworski takes this further, pinpointing whether civil society accepts the liberalization of constraints on speech and organization or whether it presses for further concessions as the key juncture in democratic transition. ${ }^{11}$

The neo-Tocquevillian notion of civil society drew its inspiration from the study of mass political behavior and consideration of the forms of political culture most congruent with democracy. This line of reasoning was opened by Almond and $\mathrm{Verba}^{12}$ who saw an expansive layer of activist citizenry as central to democracy and was advanced by Putnam, ${ }^{13}$ whose account of civic participation and government performance across Italy placed associational life at the center of the forms of social capital necessary for effective governance. Inglehart and his collaborators ${ }^{14}$ have linked a complex of values including citizen-level engagement with pro-democratic political cultures. While such foundational accounts of democratic political culture did not explicitly conceptualize this in terms of civil society, it has been recognized as such by others. ${ }^{15}$

While there has been widespread adoption and acceptance of neo-Gramscian notions of an "insurgent civil society" as a fundamental actor in contemporary democratization and a neoTocquevillian notion of a "regularized civil society of social interests" as a critical sphere in durable democracy, there have also been a number of dissenting views. Several accounts have disputed the notion of cultural congruence with democracy, arguing that the causal relationship is inverted and that social trust and citizen engagement is less central to democratic success than theorized. ${ }^{16}$ Others raise the specter of an activist civil society as a means for authoritarian mass movements to overthrow democracy. ${ }^{17}$ 
The notion of a badly behaved and overactive civil society contradicts the idea that civil society mobilization is an essential element in overcoming the inertia of authoritarianism. Such controversies find strong echo in the literature on postcommunist democratization where one set of scholars pose the problem of "weak" civil society as problematic for the building of durable democracy, ${ }^{18}$ whereas as others have seen an active and engaged civil society as an mechanism for democratic consolidation ${ }^{19}$ or as an essential component of defeating neo-authoritarian challenges to full democratization. ${ }^{20}$

Our ability to settle such fundamental questions have been to some degree impeded because the data at our disposal is limited. Theories are advocated and refuted on the basis of a relatively small number of cases, by cross-sectional data that cannot capture the full political dynamics of such relationships, constrained samples which lead to concerns about bias on the basis of what has been omitted, or different sources that present different assessments of fundamental qualities. The V-Dem data goes a long way in remedying such problems by collecting data that was previously understood as too expensive to collect or even unobservable. The team has been able to do this by accessing the "embedded knowledge" of experts and render it visible for researchers. This represents a step forward in addressing many thorny, unresolved research questions. For instance, the literature on the strength of postcommunist civil society and it ramifications lacks a consensus on whether civil society in the region is weak or developed. We will return to this particular question later in the article, but before that it is worthwhile to document the state of the data environment prior to the publication of the new V-Dem data.

\section{The Existing Data Environment}

Data to measure civil society, until now, has been difficult to collect and apply in cross-national analysis. The discussion that follows introduces the extant indicators and their limitations for doing time-series, cross-sectional type analysis. This is in no way meant to diminish the importance of the work of these authors, their measures, or the analyses based on them. Following this discussion, we 
then discuss the potential liabilities that data-poor environments can pose for making generalizable inference.

The most common measurement of civil society uses questions from the World Values Survey (WVS) on organizational and protest behavior. WVS and the various regional surveys and attitudinal barometers it has inspired are a major resource in the study of political culture. The surveys have now been conducted for over thirty years in six waves and have included as many as 50-60 countries in individual waves. ${ }^{21}$ However, the WVS is only repeated every five years due to resource constraints, alternates two different questions on organizational behavior, and does not always include the same countries, posing major challenges for studying civil society in any sort of panel or country-year set-up for a global sample.

Event history coding of protest is also an important means to study the development of civil societies in a small number of contexts over time. Such coding is very difficult and expensive to replicate over a large number of countries. The most extensive, ambitious, and sustained project of this sort has compiled annual data for four countries over a thirty year period. ${ }^{22}$ Some have also examined the registration of new organizations from statistical annuals or registries on a national level but these figures are limited in that they do not track exit or activism, and are hard to collect in comparable terms across countries. $^{23}$

Several organizations have tried to remedy these problems by measuring different components across civil societies. One of the most ambitious is the Civicus Civil Society Index that looked at four different dimensions of civil society -- "the organisational structure of civil society, civic engagement, perception of impact, practice of values and the enabling environment." ${ }^{24}$ The most recent Civicus CSI round covered 35 countries for the period $2008-11 .{ }^{25}$ Work on this measure has been suspended and has been replaced by the Civicus Civil Society Enabling Environment Index or EEI. ${ }^{26}$ 
The EEI measures the "conditions that impact on the capacity of citizens... to participate and engage in the civil society arena in a sustained and voluntary manner." The first report issued in 2013 included 108 countries. The measure is composed of 53 indicators compiled over the period from 20052012, which capture three major dimensions (socio-economic, socio-cultural, and governance) broken into 17 sub-dimensions. While very ambitious in scope and useful for policy-makers and activists, this measure, by its nature, has limited utility for statistical investigation except in basic cross-sectional analysis. $^{27}$

Two different organizations compiled a Global Civil Society Index. In 2002 the Center for the Study of Global Governance at the London School of Economics published rankings for 33 countries in Europe and the Americas circa $2000^{28}$ and the Center for Civil Society Studies at Johns Hopkins University published an index for sixteen countries also around $2000 .{ }^{29}$ Disaggregated components were compiled for thirty-six countries in an updated version. ${ }^{30}$

USAID's Civil Society Organization Sustainability Index (CSOSI) examines six dimensions -- the legal environment, organizational capacity, financial viability, advocacy, service provision, infrastructure, and public image -- and ranks them on a scale from one to five. The CSOSI is an average of the components. They have compiled the index for postcommunist Europe for the years 1997-2011 and for twenty countries in Sub-Saharan Africa in 2009-2011. ${ }^{31}$

Freedom House's Nations in Transit ${ }^{32}$ also calculates a civil society score for the postcommunist countries. It ranks civil society on a scale from one to seven based on nine open-ended questions answered by experts. The ranking on the scale is originally determined by the author of an expert report and is then reviewed by outside readers and a board of academic advisors. Rankings are available for 1995 and $1997-2013 .^{33}$

The Bertelsmann Transformation Index produces 49 scalar measures using expert opinion which are then compiled into a series of indices which gauge the extent to which the countries in question 
have transformed into liberal democratic market systems. After a pilot study in 2003, it has been compiled biennially since 2006 for 129 developing and transitional countries. It has four indicators relevant to the study of civil society - organizational freedom, the presence of interest group networks, social self-organization, and a civil society tradition. ${ }^{34}$

Last but not least, the International Institute of Social Studies in The Hague has created a set of Indicators of Social Development" (ISD) that measure aspects of civil society. They have compiled a civic participation indicator for 209 countries at five year intervals from 1990 to 2010 . Seventeen percent of the observations are missing. It is compiled from a variety of answers to values and attitudes surveys, data on international non-governmental organizations, the Civicus CSI, and data on communications technology.${ }^{35}$ The coverage of the sub-indicators is subject to a higher degree of missingness than the indicator itself. This problem is addressed through the use of percentile matching techniques rather than imputation. ${ }^{36}$ They have also compiled an indicator of "clubs and associations" from values and attitudes surveys. It is subject to a very high degree of missing observations - fifty-five percent. ${ }^{37}$

Despite the valiant efforts of those who have sought to measure civil society prior to V-Dem, the paucity of data going back in time, limited coverage of countries, and the inconsistent coverage of the same factors, hinders both good descriptive inference about and the conclusive testing of general propositions on the impact of civil society. Such problems immediately raise issues of sample bias. Are the results of tests the product of the properties of the particular countries or time periods for which we have limited data? Even renowned datasets like the World Values Survey, which strive to provide data from many regions of the globe, often over-represents Western societies, other rich societies, or those with a strong state and statistical capacity, at the expense of poorer areas and those with poorer statistical infrastructure. Given the constraints they face on funding, what they have accomplished is remarkable, but its limits represent a potential problem in supporting generalizable propositions. 
Problems of sample bias are also a concern in the case of some of the most innovative theoretical work on civil society. Take for example Sheri Berman's brilliant account of how the Nazis were able to take control of highly developed civil society organizations in Weimar Germany and use them to take power. ${ }^{38}$ This is inference based on one, albeit highly influential, case. Similarly, Dylan Riley has also explored how civil society in the interwar period in Italy, Romania, and Spain constituted the "foundation of fascism." ${ }^{39}$ Both authors argue that active civil societies unchecked by political organization are at the root of these democratic breakdowns. Both use thickly descriptive case analyses to convincingly demonstrate the causal links they theorize and for this reason the thesis they propound is influential. Yet at the same time, the theory is based on only four cases with no variation on the dependent variable.

But is civil society really a threat to democracy? Were the aristocratic enemies of democracy that Tocqueville rejected correct in hindsight? Or does the problem of selection on the dependent variable require us to be much more cautious about generalizing on this basis despite compelling withincase evidence? Such questions are now answerable using the V-Dem data and two working papers from the V-Dem team show that on balance, civil society insulates democracies from breakdown. Bernhard, Hicken, Reenock and Lindberg, looking at a global sample from 1900 to 2010 show that civil society has a strong positive effect on democratic survival. ${ }^{40}$ Cornell, Møller, and Skaaning directly look at the interwar period and find the same thing. ${ }^{41}$ Both papers also show that the interaction of V-Dem civil society variables with the degree of political party institutionalization is also not significant, so they provide no global or interwar evidence that political party strength (as perhaps the best indicator available of political organization) plays any mediating role on the impact of civil society on the survival of democratic regimes.

Thus V-Dem radically changes how we can study the impact of civil society on a range of outcomes. As noted above, and will be demonstrated below in our examination of the debate on civil 
society in postcommunist Eurasia, the diversity of civil society indicators and their coverage allows us to approach old questions with new resources and confidence in our findings. And with time, it will allow for the testing of new hypotheses on the impact of civil society on political life. We next present the VDem civil society data in its full scope.

\section{The V-Dem Civil Society Data}

Like all civil society researchers, we conceive of civil society as an essential intermediary sphere of the polity. It lies in the public space between the private sphere and the official sphere of the state. It is not the only set of actors that lie within the non-official public sphere - it shares this space with political society, a set of public actors who are consciously organized to contest the control of state power. While civil society has a degree of autonomy from the state (ranging from extensive to minimal), civil society is still regulated by the state. The state establishes a framework for the operation of civil society, and often intervenes in its life (though the degree of freedom of civil society is enhanced by less intervention). ${ }^{42}$

Civil society is populated by groups of citizens organized to act in pursuit of their interests, broadly conceived (both material and ideal). We refer to these groups of self-organized interested citizens as civil society organizations (CSOs). CSOs include, but are by no means limited to, interest groups, labor unions, religious organizations, foundations, think-tanks, social movements, professional associations, charities, and other non-governmental organizations.

It is essential to distinguish between the public and private spheres in understanding what constitutes a civil society organization. Both routine spiritual and economic activity are not civic but private. The productive activity of firms is not part of civil society, nor is the spiritual activity housed in religious institutions. However, when producers, workers, or people who share a set of spiritually grounded, political, moral or ethical beliefs organize on the basis of a shared set of interests and pursue their realization in the public space, such activity is assuredly part of civil society. 
The existence of civil society is a necessary but not sufficient condition for democracy. This means that civil society is compatible with both authoritarian and democratic political systems. Some forms of dictatorship, specifically those which enforce a monopoly on political and civil organization, abolish civil society. However, such harsh political projects, the sorts of dictatorships that have inspired the label "totalitarian," as well as some forms of authoritarianism in their harsher phases, are less common than dictatorships that permit some level of civil society organization. ${ }^{43}$

Despite a broadly shared and well-developed conceptualization of civil society in the comparative politics literature, it has been difficult and expensive to collect comparable data on it across societies and time periods. Unlike other political and social indicators (e.g. voting behavior, economic performance, coups d'état), it is not easily observable. Yet at the same time there is considerable knowledge about the state of civil society in the academic community. In that sense, the problem that VDem faced was to extract a form of hard to access embedded knowledge and make it widely available in a form researchers could use. The issue was to turn something hard to observe because it was the province of experts into a more generally accessible form of knowledge.

The V-Dem dataset has compiled 350 separate indicators, seven different indices of democracy, ${ }^{44}$ and 39 mid-level indices of democracy (e.g. rule of law, clean elections, etc.) for 173 sovereign states and territories for the period 1900 until today. ${ }^{45}$ Given the importance of civil society in recent theorizing about regimes and regime change and the difficulty in testing falsifiable hypotheses with a high degree of external validity, our aim was to produce both a series of disaggregated indicators that get at different aspects of civil society, as well as indices of civil society strength that cover a global sample of countries over an extensive period of time.

The V-Dem response to digging out this broad range of new data was to rely on the in-depth knowledge embedded in responses from country experts to questions about fundamental characteristics of critical areas of democratic development for which it is difficult, prohibitively 
expensive, or impossible to collect observational data. In the process over 2,500 country experts worldwide have contributed ratings to V-Dem. ${ }^{46}$ The country-expert data is combined into country-year estimates using a state-of-the-art Bayesian ordinal item-response theory model developed by the project's methodologists. ${ }^{47}$ The V-Dem civil society battery has ten questions that gauge different disaggregated aspects of civil society. In our discussion we will highlight five questions that were essential in building the two indices that we highlight below and employ in our discussion of civil society in postcommunist Eurasia. In addition to those five questions, V-Dem also asked questions on the organizational characteristics of civil society organizations, the presence and character of anti-system movements, and whether religious organizations were subject to discrimination in civil society. ${ }^{48}$

The test that we frame below to further demonstrate the utility and novelty of the V-Dem data on civil society will use two indices that gauge the strength of civil society in somewhat different ways. The first of these gauges is what we think of as civil society robustness, called the Core Civil Society Index (CCSI, v2xcs_ccsi). The second is a thick measure of the degree to which civil society participates in the political process, called the Civil Society Participation Index (CSPI,v2x_cspart).

We think of the robustness of civil society in terms of its ability to organize free of state constraints and how engaged the citizenry is in CSOs. We aggregate three of our indicators designed to this end to construct the CCSI, which allows us to distinguish robust from feeble civil societies. State constraints on civil society come via two different mechanisms. States may use the law to regulate the entry and exit of CSOs into the public space, determining who can organize and who cannot. A second mechanism is the direct repression of organizations and activists. These two in combination with each other constitute the organizational environment created by the state for civil society.

We capture these mechanisms using two questions from the civil society battery. The first concerns the control of CSO entry and exit by the state (v2cseeorgs). The experts were asked to assess state control of CSO entry and exit on a five-point scale from zero to four with zero representing 
monopolistic control by the state authorities to 4 representing a lack of constraint. The second question concerned the level of state repression of CSOs (v2csreprss). Here the responses ran from zero to four with zero indicating active repression by the state to liquidate CSOs and four indicating substantively no government repression or harassment of CSOs.

The degree of citizen involvement in CSOs is gauged by a third question on the participatory environment in civil society (v2csprtcpt). The experts were asked to rate individual country-years from zero to three, with zero capturing situations in which the state sponsors all organizations, thus effectively exercising a monopoly on organization as in many state socialist and state corporatist regimes. Its maximum value is three for those societies in which there are many diverse CSOs and citizens are at least occasionally active in them.

The Civil Society Participation Index was designed to create a thicker indicator of the degree to which civil society organizations are engaged in the political process. It too uses the civil society participatory environment question discussed above but thickens it with three other V-Dem indicators. Two of these come from the civil society battery. The first was a question designed to gauge the extent to which rulers routinely consult with CSOs on policies relevant to their members (v2cscnsult). The experts were asked to rate each country-year according to a three-point scale which runs from zero to two. Zero is indicative of a high degree of insulation of the government from CSOs and two indicative of regular consultation with CSOs on relevant policy issues. One is indicative of an intermediate level of consultation. This captures the extent to which civil society organizations are capable of translating their activism into impact at the level of policy.

The second additional question from the V-Dem civil society battery examines whether women are prevented from engagement in civil society (v2csgender). This is a five-point scale that runs from "almost always" to "almost never." ${ }^{49}$ Women's participation is not only intrinsically interesting in itself, but also can function as an indicator of whether traditional status barriers are an impediment to 
participation in civil society organizations in general. Finally, we also draw on one question from outside the civil society battery capturing the candidate nomination process within party organizations (v2pscnslnl). This indicator captures the extent to which candidate nomination is highly decentralized or made through party primaries. ${ }^{50}$ This item was included to gauge the extent of citizen and CSO participation in the process of representative government selection beyond voting, and therefore captures the extent to which civil society organizations are capable of translating their activism into influence on political society.

While the two measures are strongly correlated (.91), they do tap into slightly different aspects of civil society. ${ }^{51}$ The CSPI is geared purely to capturing citizen and CSO participation and its effectiveness in conveying demands to the party system and state administration, while the CCSI also takes into account how state policy shapes citizen engagement. The latter controls for the effects of state harassment and legal regulation in facilitating or encouraging citizen participation. While such constraints are often minor in democracies, they are quite important under authoritarian conditions, especially in those cases in which the regime uses forms of democratic emulation as a means to secure compliance and shore up its rule. Such considerations are important in gauging civil society strength across countries both globally and in postcommunist Eurasia where we deploy them later in the article in our tests.

\section{Creating the V-Dem Civil Society Indices}

Up until this point we have discussed the importance of civil society as a concept of central importance in the study of democracy and democratization, and how we used a subset of questions from the V-Dem data to create indices of civil society strength. We now explain the technical details of how we tapped the rich vein of expert knowledge that allowed us to create the CCSI and CSPI to serve the needs of researchers looking for a single indicator that captures the relative strength of civil society across observations. 
The construction of the indices was a two-step aggregation process. In the first stage, ordinal ratings provided by multiple country experts for the relevant variables are aggregated using a Bayesian measurement model. In the second stage, the output of these statistical models is aggregated into the indices using Bayesian factor analysis. The process by which this has been accomplished is highly transparent, for our civil society indicators and the dataset as a whole. The full codebook includes the complete battery given to the experts and details the fashion in which higher-order indices were aggregated..$^{52}$ The process by which individual coder data was aggregated into latent variable estimates by the measurement model is all extensively documented and publicly available. ${ }^{53}$ Because latent variable estimates include a degree of uncertainty, full posterior distributions for all variables are publicly available to allow researchers to verify that their findings are not a product of measurement error. We briefly review each stage of the construction of the civil society variables used here.

Since country experts provided multiple ordinal ratings for each of the variables that constitute the indices, ${ }^{54}$ the first measurement challenge is to aggregate the ordinal ratings into a unified, continuous and reliable variable. Individual raters might vary with regard to the way they interpret the questions, and in terms of reliability and consistency. Thus, we utilize Bayesian item response theory models to aggregate their diverse ratings. These models are useful because they incorporate the information encoded in the variation in raters' perceptions, and in reliability levels across and within coders into the estimation process. ${ }^{55}$ While this type of model has been widely used in political science to measure legislators' ideology based on binary data, ${ }^{56}$ their use in aggregating multi-rater ordinal data is much less common. ${ }^{57}$

The main assumption underlying item response theory is that the variable being measured is latent, i.e. cannot be measured directly, and that raters perceive the true value of the variable with some error. Importantly, the model utilizes coder ratings and patterns of disagreement across raters to estimate coder level errors, and down weights the ratings provided by coders who are deemed less 
informative. The Bayesian framework allows us to estimate the country-year latent quantity of interest (e.g. the latent degree to which CSOs are harassed by the state in a given country-year), as well as simultaneously estimating the thresholds that separate the levels of the latent variable. Put differently, the model estimates country-year level parameters that capture the latent variable of interest, along with thresholds differentiating the various levels of this latent variable. ${ }^{58}$

Expert surveys pose a problem for social scientists in terms of cross-national comparability. Coders who vary in terms of their educational and cultural backgrounds might have different perceptions of the latent variable, and may, in addition, have different latent thresholds. ${ }^{59}$ If these coders provide ratings for disjointed units, model estimates will be problematic since estimates for different countries will be based on different scales. In order to mitigate this problem, the V-Dem project has recruited a large number of bridge-coders, i.e. coders who serve as connecting units across previously disjointed countries. Extensive Monte Carlo simulations ${ }^{60}$ provide strong evidence that bridge coders indeed improve model fit and greatly increase the degree of cross-national comparability. ${ }^{61}$

In the second stage of the index construction, we generate the index scores using Bayesian factor analysis. As before, utilizing the Bayesian framework is advantageous since it allows us to generate uncertainty estimates for the index. All component variables loaded highly on the latent dimension, though the factor loadings are somewhat higher for the CCSI than the CSPI. ${ }^{62}$

In thinking about how to assure ourselves that the data generation process yielded valid indicators, we ran an extensive series of validity checks. In terms of macro-level face validity, we designed several basic tests that examined whether CCSI behaved in line with our expectations over large units of time and space. We also ran a series of discriminant validity checks that looked at the correlations between the CCSI and extant civil society indicators, as well as other measures that captured dimensions similar to its component parts. Finally, we also ran a series of convergent validity checks exploring the correlations between the CCSI and variables to which we thought it should have a 
strong relationship. These exercises helped to build our confidence that the data was capturing the latent dimensions for which it was designed. ${ }^{63}$ We next report on a series of micro-level validity checks we ran to demonstrate how the data effectively capture detailed expert knowledge on national level civil societies and make it available to the research community at large.

\section{From Embedded to Transparent Knowledge}

Our argument on why the V-Dem civil society data is a unique and potentially game-changing development in the study of civil society is based on how it has taken an embedded and difficult to access body of knowledge and made it publically available to the research community at large. The difficulty of this challenge lies in the fact that there is no set of universally available observables over a broad range of times and places that allows us to access the development of civil society in a comparative perspective. Knowledge about civil society in national contexts is widespread, yet at the same time still difficult to access because it is only at the disposal of individual scholars who have made time-intensive commitments to studying the role of the citizenry in politics.

V-Dem has been able to compile its range of civil society indicators over a substantial period of time for many countries by accessing that expert knowledge and standardizing it. By asking multiple experts on national contexts the same set of questions about different aspects of civil society we were able to compile a set of at least five expert assessments of different aspects of civil society at different places and times. The measurement model then takes those raw assessments and generates a latent variable estimate with confidence bounds that takes into account the different ways in which coders make their assessments of answers to the questions and how reliable their answers are in relation to the assessments given by the other coders. In this way the divergent assessments of coders across time and context are arrayed on the same scale, making geographic and temporal comparison possible.

To demonstrate that this process provides data that extracts a credible assessment of the development of civil society at the level of individual nation states in line with the kinds of knowledge 
possessed by country experts, we present the results of micro-level face validity checks we performed for the CCSI. Here we examine the extent to which the CCSI is congruent with the historical development of civil society in particular countries. We should observe change over time in line with particular events related to the constraints on CSOs and levels of mobilization. We chose to examine Venezuela, Ghana, and Russia based on the expertise of team members.

Venezuela's CCSI for the period 1900-2012 is displayed in Figure 1 below. It also includes the seventy percent Bayesian confidence intervals generated by the measurement model. The variation over time corresponds to three important periods. Before 1935, the country knew only military dictatorship, and civil society was tightly circumscribed. When General Gómez died in 1935, a series of transitional governments oversaw political liberalization, especially the growth of unions and political parties. This culminated in the Trienio of $1945-48$, considered by many to be Venezuela's first attempt at democracy. This period saw the rapid organization of peasant leagues and the expansion of professional associations. It was quashed by a military coup in 1948, leading the political opposition to go underground or into exile until a durable transition to democracy in 1958-59. This led to a period of great freedom for all sorts of civil society organizations, although they were heavily politicized along partisan lines.

\section{[Figure 1]}

The recent sharp decline corresponds to the government of Hugo Chávez Frías (1999-2013). The CCSI helps to illuminate this controversial period. Although his government repeatedly won elections and survived most referendums, civil society experienced many setbacks due to threats against union leaders, arrests of opposition politicians and judges, intimidation and harassment of NGOs and public employees, monitoring of political loyalties by governing-party officials and neighborhood activists, and progressive muffling of critical viewpoints in the media. Most of the change in the CCSI for Venezuela was due to two components: government attempts to repress CSOs (v2csreprss) and "moderate" 
government control over the entry and exit of CSOs into public life (v2cseeorgs). The level of participation (v2csprtcpt) remained consistent ("There are many diverse CSOs, but popular involvement is minimal") from 1959 to 2012 . Venezuela saw growing CSO independence from parties in the early 1990s and sporadic mass mobilizations in the 2000s, but not much strengthening of civil society organizations in this last period.

Figure 2 presents Ghana's CCSI over time. In the early twentieth century under British colonial rule, the moderate CCSI scores reflect that civil society organizations existed and operated with minimal interference as long as they did not challenge British rule. To that end the colonial authorities exercised a fair degree of control over which organizations were allowed to exist but otherwise were not unduly repressive nor did they particularly discourage participation in CSOs. The upward movement in the CCSI starting after World War II reflects an upsurge in activism due to the emergence of a broad-based national independence movement that succeeded in 1957.

Soon after independence the new government under Kwame Nkrumah and the Convention People's Party (CPP) called for national unity over pluralism and CSOs were subjected to increased levels of repression, including the infamous Preventive Detention Act in 1958 that gave the prime minister the power to detain individuals for up to five years without trial. Nkrumah, who was later declared president for life, tolerated no further political competition, and as Ghana became increasingly autocratic, civil society had less room to maneuver than even under colonial rule. This explains the sharp drop in the CCSI following independence.

[Figure 2]

We observe a positive change in the CCSI in 1967 following the military coup that overthrew Nkrumah in 1966, when the National Liberation Council took over and liberalized in anticipation of elections in 1969. This period of liberalization and fledgling democracy was terminated by another coup led by Lieutenant Colonel I. K. Acheampong in 1972. Continued stagnation and political gridlock led to 
two additional military coups led by Flight Lieutenant J. J. Rawlings in 1979 and 1981. Following the latter, Rawlings ushered in a longer period of nationalist-socialist rule by the Provincial National Defense Council (PNDC). The CCSI accurately captures this period when the Rawlings regime actively repressed CSOs and imposed tight controls on their entry and exit.

The CCSI grows rapidly starting in 1988-89 when the Rawlings regime opened up political and civilian space and elections to local district assemblies were rolled out. By 1991, protests and demonstrations were allowed more or less freely in Ghana, and civil society no longer feared repression from the Rawlings regime. The CCSI reflects this rapid improvement that came with democratization in 1988 to 1992 . Since then it has remained at high levels under Ghana's new period of democratic stability.

The CCSI for Russia (Tsarist, Soviet, and postcommunist) is presented in Figure 3. At the onset of the last century Tsarist Russia had a weakly developed civil society (reflected in a moderately low CCSI score) that left some latitude for organization by the nobility, the propertied, and professionals while denying it to workers, peasants, and minority nationalities. The CCSI improves slightly after the revolution of 1905 when a new constitution liberalized the rights of citizens to assemble and form associations. It then drops precipitously with the Revolution and Civil War period (1917-1921), when politics was highly chaotic and armed force ruled the day.

\section{[Figure 3]}

The institutionalization of Soviet rule in the 1920s kept the CCSI at very low levels for an extended period of time. Under the USSR, society was subjected to extensive etatization with the citizenry firmly under the control of state sponsored transmission belt organizations. Beginning with the liberalization period of Glasnost and Perestroika under Gorbachev we see a sharp upturn in the CCSI due to a relaxation of state repression and control over the organizational realm. This period saw an upsurge 
in independent organizations, a marked increase in public demonstrations, protests, strikes and the like, and a relaxation of controls on public discourse.

The upward trend continues after 1991 as the strength of civil society in Russia continued to grow in the period following the collapse of the Soviet Union and the onset of Yeltsin's rule, stabilizing at its maximum level throughout the 1990s. The decline beginning in 2000 corresponds to Putin's rule and his installation of a competitive authoritarian regime in Russia in which civil society activity has been increasingly subjected to the heavy hand of the state anew, but at levels not nearly as harsh as under Soviet rule.

Having now documented to readers that we have successfully used the expert knowledge on which our variables and indices are based to present novel and comprehensive data on the development of national civil societies over time, we will now use them to examine a controversy in the literature on civil society. Among scholars of postcommunist democratization there has been a long and determined debate over the impact of the communist experience on civil society. On the one hand, a group of scholars has seen a weak civil society as a potential impediment to successful democratization, while another set of scholars have argued that this concern is overstated.

\section{How the V-Dem Data Can Contribute to Substantive Debates: Civil Society in the Postcommunist World}

Among those who agree on the relationship between civil society and democracy, there can be disagreements over the condition of civil society, and what this ultimately means for the fate of democracy. This is particularly manifest in the discussion of democratization in postcommunist Eastern and Central Europe. On the one side there are a group of observers who see postcommunist civil society as relatively weak compared to civil society in other regions, ${ }^{64}$ and those who argue that the extant ways of measuring civil society through values and attitudes surveys miss parts of the picture, notably a vibrant development of civil society in the period since $1989 .{ }^{65}$ Instead they pose alternative 
measurement strategies based on directly observable indicators such as protest event coding, coordinated political activity by networks of CSOs, and the registration of new CSOs by the state.

Thus while there is good substantive justification to be concerned about the status of civil society among those interested in the study of democracy and its fate, the postcommunist civil society legacy debate points out the difficulties of coming to definitive answers because of the relative paucity of data. In one sense the two sides of this debate have been talking past each other due to radically different data sources. The findings that civil society is relatively weak is often based on data drawn from the answers to questions on organizational joining behavior and propensity to protest drawn from global and regional value surveys and barometers. The contradictory position comes from event data coded from newspapers on CSO formation and activity. Rather than reiterate the potential pitfalls of both forms of data, we will examine what our indices, the CCSI and CSPI, say about the relative strength of civil society in various regions.

We first examine the data for the region in a comparative descriptive perspective. Figure 4 presents the development of the CCSI and CSPI in Western Europe, Latin America, the former East Bloc, and the former Soviet Union for the period 1900 to 2012. We have chosen Western Europe as a comparison as it is a neighboring region with a history of strong civil society development in a global perspective and Latin America as an area with a recent history of regional democratization. It is clear from the outset that civil society development in both postcommunist regions lagged substantially below Western Europe during the period up to 1989. For most of the interwar and Cold War period it also lagged, but less profoundly, below Latin America, another region with a strong history of dictatorship. So historically, there is certainly evidence of a weak civil society on average in the postcommunist countries, both before and during communism.

[Figure 4] 
In the period after 1989 the levels of both indicators in the former East Bloc and the former Soviet Union increase dramatically. As in the postcommunist regions, we see strong improvement with the recent global wave of democratization in Latin America, although starting about a decade earlier there in the mid-1970s. While the levels of the post-Soviet states lag behind the three others, those in the former East Bloc have come to exceed those of Latin America and are actually higher than all regions of the globe except for Western Europe and North America (not shown in the figure). Most notably for the debate on postcommunist civil society, the strong differences between the mean scores for the former Soviet Union and the former East Bloc following 1989 seems to belie the idea of a uniform postcommunist legacy.

In the statistical tests that follow we estimate the levels of CCSI and CSPI taking into account regional location as well as two factors thought to affect the strength of civil society. ${ }^{66}$ The first of these is the existence of democracy itself and the second is the level of development. In this regard, our tests are very different from those which use micro-level data. In the most elaborate tests of that kind, the most important controls are also individual level (though some studies use multilevel models that incorporate national level data as well). Here we gauge how different regions are doing, controlling for their experience both in terms of economic and political development. Thus the work we present here is the first to engage in this debate at the macro-level.

In Table 1 we estimate the strength of civil society based on the level of development, ${ }^{67}$ degree of democracy, and a series of regional dummies. ${ }^{68}$ We also include a lagged dependent variable with the expectation that where an observation was in terms of the development of civil society in the recent past will strongly condition where it is at time $t$. We use a time-series cross-sectional design using random effects because of our desire to understand regional differences on the strength of civil society. In this regard the kind of inference we are drawing is descriptive, not causal. We are not trying to gauge why countries have different levels of CCSI or CPSI but to gauge the extent to which postcommunist 
countries are different from the rest of the regions in the world. Our sample is confined to the post-1989 period, ${ }^{69}$ the focus of the debate on the strength of postcommunist civil society. The results are presented below in table 1.

In controlling for democracy when the CCSI is the dependent variable it is essential to use a measure that does not explicitly use elements that might be partially captured by the CCSI, such as freedom of association. For that reason, our controls embody minimalist measures of democracy. We also control for different specifications of democracy. We examine both level of democracy and time spent under democracy. Thus for the quality of democracy models, we use the V-Dem Clean Elections Index (v2xel_frefair), which captures the extent that elections are free and fair and procedurally sound. ${ }^{70}$ We believe that this measure proxies well for Schumpeter's minimalist electoral notion of democracy. ${ }^{71}$ We also run models to capture whether democracy has a developmental effect over time (assuming more time under democracy will allow civil society to potentially flourish). Because there is no theoretically justified cut-point to sort democratic from non-democratic practice using the Clean Elections Index, we use the binary coding by Boix, Miller and Rossato (2015) to estimate time spent under democracy. It too uses a minimalist, electoral specification of democracy. This allows us to control for the fact that when we compare the postcommunist regions to areas of the world that democratized earlier, we capture that they are earlier in the process of the development of a democratic civil society. Table 1 presents four sets of paired models. The first four use the CCSI and the second use the CSPI. In each quartet the two first models use a level specification of democracy and the second two use the developmental (time) specification. In the first model of each pair the inclusion of a dummy for the postcommunist states gauges whether postcommunist civil society is different from the rest of the sample. In the second model in each pair we include dummy variables for other world regions to gauge whether postcommunist civil society (the reference category) is more vibrant than in other regions.

[Table 1] 
For the most part the postcommunist dummy is insignificant and inconsistently signed. In model 1.3 , it is positive and significant, but the lack of robustness across the four models leads us to discount it. When we compare the postcommunist countries to other regions things are somewhat more interesting. Postcommunist civil society outperforms that of both the Middle East and North Africa in all four models and Asia in the two CCSI models. Sub-Saharan Africa is significant and positive for the two CSPI models, indicating a higher level of participation controlling for development and democracy. The significant findings on other regional dummies are highly inconsistent and sporadic. So in this first general test we find that the strength of postcommunist civil society is neither particularly strong nor weak in comparison to a global sample, and does relatively well compared to the Middle East and North Africa and Asia.

Given what we have seen in the descriptive data above and a large range of research that shows differing postcommunist developmental trajectories between the countries of the former Soviet Union (FSU) and other postcommunist countries, ${ }^{72}$ we repeat our tests separating the FSU from former East Bloc countries (FEB).${ }^{73}$ In table two we repeat our tests with a dummy for the FEB countries and treating them as the excluded category.

[Table 2]

Our results for the FEB countries are remarkably different than the previous set of regressions. The coefficient on the FEB regional dummy is consistently positive and significant, indicating that given the region's economic and political development, civil society is highly developed from both the more structural perspective embedded in the Core Civil Society Index and the engagement perspective of the Civil Society Participation Index. It consistently outperforms the former Soviet Union, Asia, Oceania, the Middle East and North Africa, and Latin America. It even outperforms Western Europe and North America in three out of four tests. These results tell us that there is a great diversity among civil societies 
in the postcommunist region. In that spirit, we now turn to our last set of regressions, this time using the FSU countries as the comparison group.

Table three repeats out tests focusing on the subsample of postcommunist countries which were part of the FSU. The results for the FSU dummy diverge for the CCSI and CSPI. While all are negative only those for the latter are significant. This indicates that levels of civil society participation are consistently lower for the FSU countries than the rest of the global sample. In terms of the tests that compare the FSU to other regions, when we gauge the strength of civil society using the CCSI, only the FEB and Sub-Saharan Africa dummies are consistently significant and positive. For the other regions the results are insignificant or inconsistent. However, when we turn to the CSPI most regions outperform the FSU, including, again the FEB countries and Sub-Saharan Africa, Western Europe, Oceania, North America, and Latin America.

[Table 3]

We also ran a series of robustness estimations using the participatory environment variable common to both indicators. It largely confirms what we found here. The postcommunist dummy remains insignificant, and the only region that consistently performs better given its level of development and democracy is Sub-Saharan Africa. For the FEB countries the result is insignificant with level of democracy in the regression, but significant and positive for duration under democracy. With regard to other regions, the FEB countries consistently outperform the FSU countries, Asia, and Middle East and North Africa. Finally, for the regressions gauging civil society strength in the FSU the dummy is significant in both models with level of democracy and democratic duration. With regards to the other regions it is consistently weaker than the FEB countries, Western Europe, Sub-Saharan Africa, North America, and Latin America. The full results of these models are available in the on-line appendix in Table A-4. 
To sum up the results of this part of our investigation - the lack of findings for the postcommunist countries in general hides great differences among those countries that shared a communist past. The null findings in the first set of models highlight that it is difficult to generalize about postcommunist civil society. Instead what we see is a divide between those countries that were formerly part of the Soviet Bloc and those what were part of the Soviet Union. ${ }^{74}$ The former, when we control for their economic and political development, have had great success in building postcommunist civil societies. For the countries of the former Soviet Union, we can talk about a weak postcommunist civil society at least from the perspective of citizen and CSO participation. Thus we conclude that there is no uniform postcommunist malaise when it comes to civil society, but a set of two strongly diverging trajectories.

While we do not have time or space here to investigate the reasons behind the divergence between the two regions, the extant literature on legacies does provide some clues as to why this may be the case. Kopstein and Reilly attribute differences in democratic quality across the region to a process of diffusion of Western norms to those areas more geographically proximate to the West. ${ }^{75}$ Darden and Grzymala-Busse explain differences in democratic practice as a product of norms conveyed by education between states that experience independent statehood in the interwar and those which did not. ${ }^{76}$ Bernhard as well as Vachudová explain such differences in democratic performance via the engagement of opposition movements at the moment of extrication from communism. ${ }^{77}$ To the extent that these hypotheses conform to the spatial categories used in our regressions, they are plausible hypotheses and adjudicating between them must await a new round of testing.

\section{Conclusion: The Gains of Making Embedded Knowledge Transparent}

Since the emergence of civil society as an important substantive factor in our understanding of processes of democratization and the political life of democracy, our ability to pursue our theoretical insights have suffered from a shortfall of comprehensive and comparable data that would allow us to 
subject them to rigorous inferential testing to validate general knowledge about the effects of civil society. The problem was not that there was not widespread knowledge about civil society over a range of cases and time periods, but that the knowledge was maddeningly difficult to access. By using expert surveys and state of the art item response theory techniques, V-Dem has made this deeply embedded knowledge available to the larger the community of researchers over a range of indicators for the whole of the twentieth century and beyond.

Beyond its deployment in new lines of research as either the outcome of interest or an important causal factor, the availability of the data will allow us to avoid two potential pitfalls in the future. Instead of using constrained samples to make inference, we now have a data-rich environment. Thus we can avoid the pitfalls of sample bias. We illustrated the utility of the data in this regard by contrasting the findings of new V-Dem research on civil society and democratic survival with the historical work on "bad" civil society in interwar Europe. We now have substantial reason to doubt that the findings with regard to a set of influential cases in interwar Europe hold for the interwar period in general and for a more extensive global sample.

We can also see the importance of this in our testing of the proposition whether postcommunist civil society is weak. In that debate the two sides have largely argued past each other on the basis of different forms of data that did not provide comprehensive coverage of the region or the ability to definitively compare the region to the rest of the globe. We examined the question in a new perspective using different data and addressing the issue at a macro-level. Our results do not confirm either position fully. Instead we show that there is substantial variation across former postcommunist countries in terms of how civil society developed following the downfall of communism. ${ }^{78}$ The differences seem to group intra-regionally. We show a sharp divide between the former East Bloc countries which have rapidly developed in terms of civil society strength and those of the former Soviet Union which have 
lagged. Thus, using the data, we were again able to shed new light on a major controversy in the literature.

The second pitfall concerns omitted variable bias. In the future if researchers believe that civil society has substantial impact on outcomes of interest or that the status of civil society presents endogeneity concerns with regards to outcomes, there is now data to gauge different aspects of civil society as an independent variable or to control for it when trying to gauge the impact of other independent variables. Our findings on postcommunist civil society have important implications for the future investigation of questions concerning postcommunist politics with regard to omitted variable bias. One strong assumption about postcommunist politics is that the shared starting point of these countries makes it reasonable to think about them in a most similar systems research design framework. Such frameworks facilitate the problem of control. Our research shows that there is substantial variation across the postcommunist states in the development of civil society. This means that is not possible to assume that such states share the same legacy with regard to civil society. Thus future research into questions in which variation in civil society can function as a confounder need to take this diversity into account. This points out that the absence of data on civil society potentially has led in the past to omitted variable bias in estimating the effects of independent variables on outcomes.

The gains provided by the V-Dem data are not limited to the academic community. By making civil society and other key factors relevant to the study of regimes and politics in general, practitioners in the policy community also have a new and powerful tool at their disposal. V-Dem has not only made its data available to the academic community but has put the data on-line in a form that is much more accessible through on-line graphing tools for the policy community, and its use in classrooms by educators at all levels (including versions in French, Spanish, Russian, and Arabic). It includes a variety of different graphs, drill-down features, and motion charts. ${ }^{79}$ 
By making embedded knowledge transparent the data allows practitioners to get a sense of what the collective judgement of experts on how different aspects of democracy have developed over time in specific contexts. One of the comparative advantages of V-Dem is that it is based on the collective judgement of several experts, whose reliability and consistency has been evaluated in comparison to other expert coders through the measurement model. In that sense the data is less liable to individual coder bias. When practitioners make use of the confidence levels on the estimates that VDem provides, it also provides a greater degree of transparency about the degree to which they should be skeptical of our assessments. Of course, such distillations of knowledge are not a substitute for practitioners developing their own in-depth understanding, but they can serve as an aid in making sense of the particular problems they would like to address.

We close this piece with a consideration on forms of knowledge in political science.

Varieties of Democracy is an unprecedentedly extensive and comprehensive undertaking in comparative politics. It is unique in the ways that it brings together two sides of comparative politics - the large-n cross-national and the in-depth country specific. By utilizing the resources of those with in-depth country knowledge, V-Dem has been able to provide indicators on arenas of democratic political life for which we had little or no data in the past. In this sense it has taken an underutilized and, lately for a good part of the discipline, an underappreciated resource and has created something unprecedented. Utilizing the collective effort of literally thousands of colleagues it has been able to compile indicators for important aspects of politics which until recently were seen as difficult to observe, if not unobservable, such as civil society. This accomplishment has been a product of both cutting edge quantitative methods and the commitment of many comparativists to deeply understanding specific countries and regions. It is thus critical, despite the vast leaps and bounds that the discipline has taken in terms of quantitative methods and data collection in the last two decades, to not lose track of the importance of the passion and commitment that individual comparativists bring to the study of specific 
places. Without that store of knowledge, and its reproduction in future generations of scholars, our ability to undertake and successfully execute innovative data collection projects like V-Dem will not have be possible. That embedded knowledge is the basis on which V-Dem's ability to make heretofore murky areas legible to a wider audience.

\section{Notes}

${ }^{1}$ The full battery is available in the V-Dem Codebook (Coppedge et al. 2016, 235-248).

${ }^{2}$ Ferguson [1767] 1995.

${ }^{3}$ Hegel [1820] 2001, Marx [1843] 1978.

${ }^{4}$ Bobbio 1988, Cohen and Arato 1994, Keane 1998.

${ }^{5}$ Gramsci 1971.

${ }^{6}$ Tocqueville [1820] 2004.

${ }^{7}$ Stepan 1985, 1988.

${ }^{8}$ Arato [1981] 1993.

${ }^{9}$ Kołakowski 1974.

${ }^{10}$ O'Donnell and Schmitter 1986, 49.

${ }^{11}$ Przeworski 1991.

12 Almond and Verba 1963.

13 Putnam 1993.

${ }^{14}$ E.g., Inglehart and Welzel 2005, Welzel et al. 2006.

${ }^{15}$ Edwards and Foley 1999.

${ }^{16}$ Barry 1970, Seligson and Muller 1994, Encarnación 2003, Rothstein 2005.

${ }^{17}$ Berman 1997, Chambers and Kopstein 2001, Riley 2010.

${ }^{18}$ Howard 2003.

${ }^{19}$ Ekiert and Kubik 1996. 
${ }^{20}$ Bunce and Wolchik 2011.

${ }^{21}$ World Values Survey 2013.

${ }^{22}$ The Logic of Civil Society in New Democracies project continues the coding pioneered by Ekiert and Kubik in their original study on East Central Europe. The expanded study relies on extensive teams of researchers in Hungary, Poland, South Korea and Taiwan. See Ekiert and Kubik 1999, Ekiert, Kubik, and Wentzel forthcoming 2017.

${ }^{23}$ Ekiert and Foa 2012, Fernandes and Branco 2013.

${ }^{24}$ Civicus 2012.

${ }^{25}$ Civicus 2011.

${ }^{26}$ Civicus 2013.

${ }^{27}$ Ibid.

${ }^{28}$ Anheier and Stares 2002.

${ }^{29}$ Center for Civil Society Studies 2004.

${ }^{30}$ Salamon, Sokolowski, and Associates 2004, chapter 2.

${ }^{31}$ USAID 2012a, 2012b.

${ }^{32}$ Freedom House 2012.

${ }^{33} \mathrm{lbid}$.

${ }^{34}$ Bertelsmann Stifftung 2014, 122-127.

${ }^{35}$ Institute of Social Studies 2015a.

${ }^{36}$ Foa and Tanner 2012.

${ }^{37}$ Institute of Social Studies 2015b.

${ }^{38}$ Berman 1997.

${ }^{39}$ Riley 2010.

${ }^{40}$ Bernhard, Hicken, Reenock, and Lindberg 2015. 
${ }^{41}$ Cornell, Møller, and Skaaning 2015.

${ }^{42}$ Foundational works on the understanding of civil society from the structural perspective employed here include Arato [1981] 1993 and Stepan 1985. Linz and Stepan 1996 provides further elaboration of this structural perspective.

${ }^{43}$ Linz and Stepan 1996.

${ }^{44}$ Electoral, liberal, majoritarian, consensus, deliberative, egalitarian, and participatory.

${ }^{45}$ Coppedge et al. 2011, V-Dem 2016a.

${ }^{46}$ Coppedge et al. 2016b, 2016c.

${ }^{47}$ Pemstein et al. 2015.

${ }^{48}$ The full battery is available in the V-Dem Codebook (V-Dem 2016a, 235-248).

${ }^{49}$ V-Dem 2016a, 237.

${ }^{50}$ See V-Dem 2016a, 128 for the full wording.

${ }^{51}$ See Table A-1 in the online appendix for the correlations between the two indices and the civil society participatory environment indicator that we use as the dependent variables in our models below.

52 Coppedge et al. 2016a.

${ }^{53}$ See Coppedge et al. 2016c and Pemstein, Tzelgov, and Wang 2015. In addition, the whole process of the construction of the V-Dem dataset will be further documented in a forthcoming volume under contract with Cambridge University Press tentatively titled "Varieties of Democracy: Measuring a Century of Political Change."

${ }^{54}$ Taking the CCSI as an example, the average numbers of country coders for the variables are 5.15 for v2cseeorgs, 5.05 for v2csprtcpt, and 5.11 for v2csreprss.

${ }^{55}$ Bollen and Paxton 2000, Jackman 2004.

${ }^{56}$ E.g., Clinton et al. 2004. 
${ }^{57}$ Cf. Pemstein et al. 2010, Schnakenberg and Farris 2014.

${ }^{58}$ Since we are using a Bayesian framework, the model provides full posterior distributions for each parameter. Our point estimates are the means of these distributions. In addition, we leverage a hierarchical structure in which we estimate coder specific thresholds (also known as difficulty parameters in the psychometric literature), and cluster these around country-level thresholds, which are based on the country for which a given rate has provided the longest time series. In turn, these countrylevel thresholds are modeled as random deviations from global, variable level thresholds.

${ }^{59}$ King and Wand 2006.

${ }^{60}$ Using the rstan library in $\mathrm{R}$, we ran all models for 500 iterations, with a burn-in period of 1000 iterations. All standard diagnostics tests suggested model convergence.

${ }^{61}$ Pemstein et al. 2015.

${ }^{62}$ See Table A-2 and A-3 in the online Appendix.

${ }^{63}$ These validity checks are reported in Bernhard, Jung, Tzelgov, Coppedge, and Lindberg 2015, 14-18 and 20-23.

${ }^{64}$ Howard 2003, Bernhard and Karakoc 2007, Pop-Eleches and Tucker 2013.

${ }^{65}$ Ekiert and Kubik 1996, Petrova and Tarrow 2007, Ekiert and Foa 2012, Ekiert, Kubik, and Wenzel 2017.

${ }^{66}$ We utilize version 6.2 of the V-Dem Data for these analyses (Coppedge et al. 2016b).

${ }^{67}$ The GDP per capita data come from the Maddison project, which have been uploaded into the V-Dem Data. See Bolt and Zanden 2014.

${ }^{68}$ The eight regional dummies are modified versions of $\mathrm{V}$-Dem's regional indicators (V-Dem 2016d). For the postcommunist countries, we include the countries in the Balkans, East/Central Europe, the Caucasus, and Central Asia (except Afghanistan), plus Mongolia. Western Europe includes the Nordic countries, Southern and Western Europe. All Asian sub-regions and Afghanistan are categorized into 
Asia. Sub-Saharan Africa consists of Central Africa, East/Horn of Africa, Southern Africa, and West Africa. The Caribbean, Central and South America are combined into Latin America. The other three regions Oceania, Middle East/North Africa, and North America - follow V-Dem.

${ }^{69}$ We end our sample in 2012, the last year for which V-Dem 6.2 has full data for all 173 countries.

${ }^{70}$ For an in-depth discussion of the variable see V-Dem 2016a, 54.

71 "The democratic method is that institutional arrangement for arriving at political decisions which realizes the common good by making the people itself decide issues through the election of individuals who are to assemble in order to carry out its will." (Schumpeter 2003, 250).

${ }^{72}$ Darden and Grzymala-Busse 2007, Kopstein and Reilly 2000, Pop-Eleches 2007, Smyth 2006.

${ }^{73}$ The FSU countries include: Armenia, Azerbaijan, Belarus, Georgia, Kyrgyzstan, Russia, Tajikistan, Ukraine, Uzbekistan, Estonia, Latvia, Lithuania, Moldova, Kazakhstan, and Turkmenistan. The FEB countries include: Mongolia, Czech Republic, Slovakia, Hungary, Poland, Romania, Albania, Bulgaria, Bosnia and Herzegovina, Croatia, Kosovo, Macedonia, Montenegro, Serbia, and Slovenia.

${ }^{74}$ Of course there are also differences within these regional subsamples as well. For instance, the Baltic states do much better than the rest of the post-Soviet sample. Including them in the FSU though, makes the test to find differences harder, though this difference opens the possibility for new theories to explain the diversity of postcommunist experience.

${ }^{75}$ Kopstein and Reilly 2000.

${ }^{76}$ Darden and Grzymala-Busse 2006.

${ }^{77}$ Bernhard 2015, Vachudová 2005.

${ }^{78}$ We thus give strong empirical backing to the recent theoretical assertions on the diversity of postcommunist civil societies by Ekiert and Kubik 2014.

${ }^{79}$ V-Dem Institute 2015. 


\section{References}

Almond, Gabriel, and Sidney Verba. 1963. The Civic Culture: Political Attitudes and Democracy in Five Nations. Princeton: Princeton University Press.

Anheier, Helmut and Sally Stares. 2002. "Introducing the Global Civil Society Index," in Global Civil Yearbook 2002, Marlies Glasius, Mary Kaldor and Helmut Anheier, eds. Oxford: Oxford University Press. 241-255.

Arato, Andrew. [1981] 1993. "Civil Society and the State, Poland 1980-81," in From Neo-Marxism to Democratic Theory. Armonk, New York: M.E. Sharpe. 71-211.

Berman, Sheri. 1997. "Civil Society and the Collapse of the Weimar Republic." World Politics, 49(3), 401429.

Bernhard, Michael. 2016. “The Moore Thesis: What's Left after 1989?” Democratization 23(1): 118-140.

Bernhard, Michael, Allen Hicken, Christopher Reenock and Staffan I. Lindberg. 2015. "Institutional Subsystems and the Survival of Democracy: Do Political and Civil Society Matter?" Varieties of Democracy Institute: Working Paper No. 4. https://v-dem.net/media/filer public/62/8e/628e4e08-ffb445ee-84c5-a25032d1b0dc/v-dem working paper 2015 4.pdf

Bernhard, Michael, Dong-Joon Jung, Eitan Tzelgov, Michael Coppedge, Staffan I. Lindberg. 2015. "The Varieties of Democracy Core Civil Society Index." Varieties of Democracy Institute: Working Paper No. 13. https://v-dem.net/media/filer public/47/2e/472eec11-830f-4578-9a09-d9f8d43cee3a/vdem working paper 201513 edited.pdf

Bernhard, Michael and Ekrem Karakoç. 2007. "Civil Society and the Legacies of Dictatorship." World Politics 59(4): 539-567.

Bertelsmann Stiftung. 2014. Transformation Index BTI 2014. Guetersloh, Germany: Verlag Bertelsmann Stiftung.

Barry, Brian. 1970. Sociologists, Economists, and Democracy. Chicago: University of Chicago Press.

Bobbio, Norberto. 1988. "Gramsci and the Concept of Civil Society," in Civil Society and the State, John Keane, ed. London: Verso. 73-99.

Boix, Carles, Michael K. Miller, and Sebastian Rosato. 2015. "Dichotomous coding of democracy, 18002010," Version 2.0. https://b2998732-a-62cb3a1a-s-sites.googlegroups.com/site/mkmtwo/CodebookBMRv2.0.pdf (accessed August 1, 2015).

Bollen, Kenneth A. and Pamela Paxton. 2000. "Subjective Measures of Liberal Democracy." Comparative Political Studies 37(1), 58-86. 
Bolt, Jutta and Jan Luiten van Zanden. 2014. "The Maddison Project: Collaborative Research on Historical National Accounts." The Economic History Review 67(3), 627-651.

Bunce, Valerie and Wolchik, Sharon. 2011. Defeating Authoritarian Leaders in Postcommunist Countries. Cambridge: Cambridge University Press.

Center for Civil Society Studies. 2004. Global Civil Society Index" http://ccss.jhu.edu/wpcontent/uploads/downloads/2011/12/Civil-Society-Index FINAL 11.15.2011.pdf (Accessed August 2, 2013).

Chambers, Simone and Jeffrey Kopstein. 2001. "Bad Civil Society." Political Theory 29(6), 837-865.

Civicus. 2011. "Civil Society Index: Key Findings from 2008-2011. http://www.civicus.org/news-andresources-127/602-civicus-civil-society-index-key-findings-from-2008-2011 (Accessed August 2, 2013).

Civicus. 2012. "The Origins of the Classic CSI." http://www.civicus.org/what-we-do-126/csi/classic-csi (Accessed August 2, 2013).

Civicus. 2013. The Civicus 2013 Enabling Environment Index. http://www.civicus.org/downloads/2013EEl\%20REPORT.pdf (Accessed June 14, 2015).

Clinton, Joshua, Simon Jackman, and Douglas Rivers. 2004. "The Statistical Analysis of Roll Call Data." American Political Science Review 98(2), 355-370.

Cohen, Jean and Andrew Arato. 1994. Civil Society and Political Theory. Cambridge: MIT Press.

Coppedge, Michael and John Gerring, with David Altman, Michael Bernhard, Steven Fish, Allen Hicken, Matthew Kroenig, Staffan I. Lindberg, Kelly McMann, Pamela Paxton, Holli A. Semetko, Svend-Erik Skaaning, Jeffrey Staton, and Jan Teorell. 2011. "Conceptualizing and Measuring Democracy: A New Approach." Perspectives on Politics 9(2), 247-267.

Coppedge, Michael, John Gerring, Staffan I. Lindberg, Svend-Erik Skaaning, Jan Teorell, David Altman, Frida Andersson, Michael Bernhard, M. Steven Fish, Adam Glynn, Allen Hicken, Carl Henrik Knutsen, Kelly McMann, Valeriya Mechkova, Farhad Miri, Pamela Paxton, Daniel Pemstein, Rachel Sigman, Jeffrey Staton, And Brigitte Zimmerman. 2016a. "V-Dem Codebook v6." Varieties of Democracy (V-Dem) Project.

Coppedge, Michael, John Gerring, Staffan I. Lindberg, Svend-Erik Skaaning, Jan Teorell, David Altman, Frida Andersson, Michael Bernhard, M. Steven Fish, Adam Glynn, Allen Hicken, Carl Henrik Knutsen, Kyle L. Marquardt, Kelly McMann, Valeriya Mechkova, Farhad Miri, Pamela Paxton, Josefine Pernes, Daniel Pemstein, Jeffrey Staton, Natalia Stepanova, Eitan Tzelgov, Yi-ting Wang, and Brigitte Zimmerman. 2016b. "V-Dem [Country-Year/Country-Date] Dataset v6." Varieties of Democracy (V-Dem) Project.

Coppedge, Michael, John Gerring, Staffan I. Lindberg, Svend-Erik Skaaning, Jan Teorell, Frida Andersson, Kyle L. Marquardt, Valeriya Mechkova, Farhad Miri, Daniel Pemstein, Josefine Pernes, Natalia Stepanova, Eitan Tzelgov, and Yi-ting Wang. 2016c. "V-Dem Methodology v6." Varieties of Democracy (V-Dem) Project.

Coppedge, Michael, John Gerring, Staffan I. Lindberg, Svend-Erik Skaaning, Jan Teorell, and Vlad Ciobanu. 2016d. "V-Dem Country Coding Units v6." Varieties of Democracy (V-Dem) Project. 
Cornell, Agnes, Jørgen Møller, and Svend-Erik Skanning. 2015. "Democracy on Retreat: Crisis, StateSociety Relations, and the Recurrence of Autocracy in the Interwar Years." Paper presented at the Council for European Studies Annual Conference, Paris, July 8-10, 2015.

Darden, Keith, and Anna Grzymala-Busse. 2006. "The Great Divide: Literacy, Nationalism, and the Communist Collapse," World Politics 59: 83-115.

Edwards, Bob, and Robert W. Foley. 1999. "Civil Society and Social Capital beyond Putnam." American Behavioral Scientist 42(1), 124-139.

Ekiert, Grzegorz. 1996. The State against Society. Princeton: Princeton University Press.

Ekiert, Grzegorz and Jan Kubik. 1999. Rebellious Civil Society. Ann Arbor: University of Michigan Press.

Ekiert, Grzegorz and Jan Kubik. 2014. "Myths and Realities of Civil Society," Journal of Democracy 25(1), 46-58.

Ekiert, Grzegorz, Jan Kubik, and Michal Wentzel. Forthcoming 2017. "Civil Society and the Three Inequalities in Contemporary Poland." Comparative Politics.

Ekiert, Grzegorz and Roberto Foa. 2012. "The Weakness of Post-Communist Civil Society Reassessed," CES Papers - Open Forum 11, http://www.scribd.com/doc/107064389/The-Weakness-of-PostCommunist-Civil-Society-Reassessed (Accessed August 1, 2013).

Encarnación, Omar G. 2003. The Myth of Civil Society: Social Capital and Democratic Consolidation in Spain and Brazil. New York: Palgrave Macmilllian.

Ferguson, Adam. [1767] 1995. An Essay on the History of Civil Society. London: Transaction Publishers.

Fernandes, Tiago and Rui Branco. 2013. "Civil Society and the Quality of Democracy: Portugal, 1974 2010," Presented at the 20th International Conference of Europeanists, Amsterdam, June 2013.

Foa, Roberto and Jeffery C. Tanner. 2012. "Methodology of the Indices of Social Development," Working Paper No. 2012-4. Rotterdam, Erasmus University, International Institute of Social Studies.

Freedom House. 2012. "Nations in Transit: Methodology,"

http://www.freedomhouse.org/template.cfm?page=352\&ana page=330\&year=2006 (Accessed August 2, 2013).

Gramsci, Antonio. 1971. Selections from the Prison Notebooks of Antonio Gramsci. Edited and translated by Hoare. Q. and G.N. Smith. New York and London: International Publishers, Lawrence and Wishart.

Hegel, Georg Wilhelm Friedrich. [1820] 2001. The Philosophy of Right. Kitchener, ONT: Batoche Books.

Howard, Marc. 2003. The Weakness of Civil Society in Post-Communist Europe. Cambridge: Cambridge University Press.

Inglehart, Ronald and Christian Welzel. 2005. Modernization, Cultural Change and Democracy.

Cambridge: Cambridge University Press.

Institute of Social Studies. 2015a. Civic Participation. Erasmus University, Rotterdam. http://www.indsocdev.org/civic-activism.html (Accessed June 15, 2015). 
Institute of Social Studies. 2015b. Clubs and Associations. Erasmus University, Rotterdam. http://www.indsocdev.org/clubs-and-associations.html (Accessed June 15, 2015).

Jackman, Simon. 2004. "What Do We Learn from Graduate Students Committees? A Multiple Rater, Latent Variable Model, with Incomplete and Continuous Indicators." Political Analysis 12(4), 400-424.

Keane, John. 1998. Civil Society: Old Images, New Visions. Cambridge: Polity Press.

King, Gary and Jonathan Wand. 2007. "Comparing Incomparable Survey Responses: Evaluating and Selecting Anchoring Vignettes." Political Analysis 15(1), 46-66.

Kołakowski, Leszek. 1974. "The Myth of Human Self-Identity," in The Socialist Idea: A Reappraisal, Leszek Kołakowski and Stuart Hampshire, eds. New York: Basic Books. 18-35.

Kopstein, Jeffrey, and David A. Reilly 2000. "Geographic Diffusion and the Transformation of the Postcommunist World," World Politics 53: 1-37.

Linz, Juan and Alfred Stepan. 1996. Problems of Democratic Transition and Consolidation: Southern Europe, South America, and Post-Communist Europe. Baltimore: Johns Hopkins University Press.

Marx, Karl. [1843] 1978. "On the Jewish Question," in The Marx-Engels Reader, Robert Tucker, ed. New York: Norton \& Company. 26-46.

O'Donnell, Guillermo, and Philippe Schmitter. 1986. "Tentative Conclusions about Uncertain Democracies," in Transitions from Authoritarian Rule, Vol. 4, Guillermo O'Donnell, Phillippe Schmitter, and Laurence Whitehead, eds. Baltimore, Johns Hopkins. 1-72.

Pemstein, Dan, Stephen A. Meserve and James Melton. 2010. "Democratic Compromise: A Latent Variable Analysis of Ten Measures of Regime Type." Political Analysis 18(4), 426-449.

Pemstein, Dan, Eitan Tzelgov, and Yi-ting Wang. 2015. "Evaluating and Improving Item Response Theory Models for Cross-National Expert Surveys". Varieties of Democracy Institute: Working Paper No. 1.

Petrova, Tsveta and Sidney Tarrow. 2007. "Transactional and Participatory Activism in the Emerging European Polity: The Puzzle of East-Central Europe," Comparative Political Studies 40(1), 74-94.

Pop-Eleches, Grigore. 2007. "Historical Legacies and Postcommunist Regime Change," Journal of Politics 69: 908-926.

Pop-Eleches, Grigore and Joshua Tucker. 2013. "Associated with the Past? Communist Legacies and Civic Participation in Post-Communist Countries." East European Politics and Societies 27(1), 45-68.

Przeworski, Adam. 1991. Democracy and the Market. Cambridge: Cambridge University Press.

Putnam, Robert. 1993. Making Democracy Work. Civic Traditions in Modern Italy. Princeton: Princeton University Press.

Riley, Dylan J. 2010. The Civic Foundations of Fascism in Europe: Italy, Spain, and Romania 1870-1945. Baltimore: Johns Hopkins University Press.

Rothstein, Bo. 2005. Social Traps and the Problem of Trust. Cambridge: Cambridge University Press. 
Salamon, Lester M., S. Wojciech Sokolowski, and Associates. 2004. Global Civil Society: Dimensions of the Nonprofit Sector, Volume Two. Bloomfield, CT: Kumarian Press.

Schnakenberg, Keith E. and Christopher Farris J. 2014. "Dynamic Patterns of Human Rights Practices." Political Science Research and Methods 2(1), 1-31.

Schumpeter, Joseph. 2003. Capitalism, Socialism and Democracy. London: Routledge.

Seligson, Mitchell, and Edward Muller. 1994. "Civic Culture and Democracy: The Question of Causal Relationships." American Political Science Review 88(3), 635-654.

Smyth, Regina. 2006. Candidate Strategies and Electoral Competition in the Russian Federation: Democracy without Foundation. Cambridge: Cambridge University Press.

Stepan, Alfred. 1985. "State Power and the Strength of Civil Society in the Southern Cone of Latin America," in Bringing the State Back In, Peter B. Evans, Dietrich Rueschemeyer, and Theda Skocpol, eds. Cambridge: Cambridge University Press. 317-346.

Stepan, Alfred. 1988. Rethinking Military Politics. Princeton: Princeton University Press.

Tocqueville, Alexis de. [1820] 2004. Democracy in America. New York: Library of America.

USAID. 2012a. "2011 CSO Sustainability Index for Sub-Saharan Africa," http://www.usaid.gov/africacivilsociety (Accessed August 3, 2013).

USAID. 2012b. "The 2011 CSO Sustainability Index for Central and Eastern Europe and Eurasia," http://transition.usaid.gov/locations/europe eurasia/dem gov/ngoindex/(Accessed August 3, 2013).

V-Dem Institute. 2015. "How to Use V-Dem Online Analysis Tools," Varieties of Democracy (V-Dem) Project. https://www.v-dem.net/media/filer public/00/65/0065c989-43ee-4663-91ce449a88e90afo/manual online tools.pdf (Accessed September 27, 2016).

V-Dem Institute. 2016. "Posteriors - Varieties of Democracy v.6." Varieties of Democracy (V-Dem) Project. https://curate.nd.edu/collections/und:kh04dn4278m

Vachudová, Milada Anna. 2005. Europe Undivided: Democracy, Leverage, and Integration after Communism. New York: Oxford University Press.

Welzel, Christian, Ronald F. Inglehart, and Franziska Deutsch. 2005. "Social Capital, Voluntary Associations and Collective Action: Which Aspects of Social Capital Have the Greatest 'Civic' Payoff?" Journal of Civil Society 1(2), 121-146.

World Values Survey. 2013. "Documentation of the Values Surveys," http://www.wvsevsdb.com/wvs/WVSDocumentation.jsp?Idioma=I (accessed August 3, 2013). 
Making Embedded Knowledge Transparent: How the V-Dem Dataset Opens New Vistas in Civil Society Research

\author{
Michael Bernhard \\ Ehrlich Chair of Political Science \\ University of Florida \\ Dong-Joon Jung \\ Senior Researcher \\ Institute for Peace and Unification Studies \\ Seoul National University \\ Eitan Tzelgov \\ Lecturer in Politics \\ University of East Anglia \\ Michael Coppedge \\ Professor of Political Science \\ University of Notre Dame \\ Staffan I. Lindberg \\ Professor of Political Science and Director, V-Dem Institute \\ University of Gothenburg
}

Corresponding author: Bernhard at ufl dot edu 


\section{On-Line Appendix}

Making Embedded Knowledge Transparent: How the V-Dem Opens New Vistas in Civil Society Research

Table A-1: Pairwise Correlations between the Civil Society Participatory Environment, the Core Civil Society Index, and Civil Society Participation Index Indicators

\begin{tabular}{|c|c|c|c|}
\hline & v2csprtcpt & v2xcs_ccsi & v2x_cspart \\
\hline v2csprtcpt & 1.0000 & & \\
\hline v2xcs_ccsi & 0.8468 & 1.0000 & \\
\hline v2x_cspart & 0.8876 & 0.9068 & 1.0000 \\
\hline
\end{tabular}

Table A-2: Factor analysis scores for CSPI components

\begin{tabular}{|l|l|l|}
\hline Variable & Loading & Uniqueness \\
\hline v2cscnsult & 0.84 & 0.24 \\
\hline v2csprtcpt & 0.81 & 0.31 \\
\hline v2csgender & 0.62 & 0.58 \\
\hline v2pscnslnl & 0.66 & 0.54 \\
\hline
\end{tabular}

10,000 MCMC iterations with 5,000 iterations as burn-in. Chains $=1$, thin $=10$. Examination of trace and posterior density plots provide evidence that the MCMC chain has reached its stationary distribution.

Table A-3: Factor analysis scores for CCSI components

\begin{tabular}{|l|l|l|}
\hline Variable & Loading & Uniqueness \\
\hline v2cseeorgs & 0.96 & 0.07 \\
\hline v2csreprss & 0.89 & 0.19 \\
\hline v2csprtcpt & 0.81 & 0.32 \\
\hline
\end{tabular}

15,000 MCMC iterations with 10,000 iterations as burn-in. Chains $=1$, thin $=10$. Examination of trace and posterior density plots provide evidence that the MCMC chain has reached its stationary distribution. 
Table A-4: Relative Strength of Civil Society Participatory Environment Using Random Effects TSCS Regressions

\begin{tabular}{|c|c|c|c|c|c|c|c|c|c|c|c|c|}
\hline \multirow{3}{*}{$\begin{array}{l}\text { Model } \\
\text { Reference Category } \\
\text { Lagged DV }\end{array}$} & 4.1 & 4.2 & 4.3 & 4.4 & 4.5 & 4.6 & 4.7 & 4.8 & 4.9 & 4.10 & 4.11 & 4.12 \\
\hline & \multicolumn{4}{|c|}{ Postcommunist } & \multicolumn{4}{|c|}{ Fomer Eastern Bloc } & \multicolumn{4}{|c|}{ Former Soviet Union } \\
\hline & $\begin{array}{l}0.903^{* * *} \\
(0.017)\end{array}$ & $\begin{array}{l}0.893^{* * *} \\
(0.017)\end{array}$ & $\begin{array}{l}0.9222^{* * *} \\
(0.015)\end{array}$ & $\begin{array}{l}0.910{ }^{* * *} \\
(0.016)\end{array}$ & $\begin{array}{l}0.909^{* * *} \\
(0.015)\end{array}$ & $\begin{array}{l}0.894^{* * *} \\
(0.017)\end{array}$ & $\begin{array}{l}0.9233^{* * *} \\
(0.015)\end{array}$ & $\begin{array}{l}0.908^{* * *} \\
(0.016)\end{array}$ & $\begin{array}{l}0.8999^{* * *} \\
(0.017)\end{array}$ & \begin{tabular}{|l|}
$0.894^{* * *}$ \\
$(0.017)$
\end{tabular} & $\begin{array}{l}0.9177^{* * *} \\
(0.016)\end{array}$ & $\begin{array}{l}0.9088^{* * *} \\
(0.016)\end{array}$ \\
\hline Logged GDP/capita (Divided by 1000) & $\begin{array}{l}-18.745 \text { ** } \\
(9.215)\end{array}$ & \begin{tabular}{|l}
-1.969 \\
$(12.429)$
\end{tabular} & $\begin{array}{l}-11.403 \\
(10.060)\end{array}$ & \begin{tabular}{|c|}
13.424 \\
$(12.992)$
\end{tabular} & $\begin{array}{l}-20.626 \text { ** } \\
(8.781)\end{array}$ & $\begin{array}{l}-1.112 \\
(11.976)\end{array}$ & $\begin{array}{l}-16.882 * \\
(9.162)\end{array}$ & \begin{tabular}{|l|}
12.432 \\
$(12.438)$
\end{tabular} & $\begin{array}{l}-16.272 * \\
(9.479)\end{array}$ & $\begin{array}{l}-1.112 \\
(11.976)\end{array}$ & $\begin{array}{l}-5.514 \\
(9.815)\end{array}$ & $\begin{array}{l}12.432 \\
(12.438)\end{array}$ \\
\hline Clean Election Index & $\begin{array}{l}0.1811^{* * *} \\
(0.040)\end{array}$ & $\begin{array}{l}0.1666^{* * *} \\
(0.042)\end{array}$ & & & $\begin{array}{l}0.167^{* * *} \\
(0.039)^{*}\end{array}$ & $\begin{array}{l}0.148^{* * *} \\
(0.039)\end{array}$ & & & $\begin{array}{l}0.176^{* * *} \\
(0.039)\end{array}$ & $\begin{array}{l}0.148^{* * *} \\
(0.039)\end{array}$ & & \\
\hline Decades of Democracy & & & $\begin{array}{l}0.0111^{* * *} \\
(0.004)\end{array}$ & $\begin{array}{c}0.005 \\
(0.004)\end{array}$ & & & $\begin{array}{l}0.013^{* * *} \\
(0.004)\end{array}$ & $\begin{array}{c}0.004 \\
(0.004)\end{array}$ & & & $\begin{array}{l}0.009 * * \\
(0.004)\end{array}$ & $\begin{array}{l}0.004 \\
(0.004)\end{array}$ \\
\hline Regions & & & & & & & & & & & & \\
\hline Postcommunist Eurasia & $\begin{array}{l}-0.027 \\
(0.022)\end{array}$ & & $\begin{array}{c}0.005 \\
(0.024)\end{array}$ & & & & & & & & & \\
\hline Former Soviet Union & & & & & & $\begin{array}{l}-0.1111^{* * *} \\
(0.034)\end{array}$ & & $\begin{array}{l}-0.135 \quad * * * \\
(0.035)\end{array}$ & $\begin{array}{l}-0.080 * * * \\
(0.029)\end{array}$ & & $\begin{array}{l}-0.070 \quad * * \\
(0.030)\end{array}$ & \\
\hline Former East Bloc & & & & & $\begin{array}{c}0.035 \\
(0.022)\end{array}$ & & $\begin{array}{l}0.081 * * * \\
(0.022)\end{array}$ & & & $\begin{array}{l}0.1111^{* * *} \\
(0.034)\end{array}$ & & $\begin{array}{l}0.135^{* * *} \\
(0.035)\end{array}$ \\
\hline Western Europe & & $\mid \begin{array}{c}0.0677^{* *} \\
(0.034)\end{array}$ & & $\begin{array}{c}0.049 \\
(0.033)\end{array}$ & & \begin{tabular}{|c|}
0.014 \\
$(0.035)$
\end{tabular} & & $\begin{array}{l}-0.015 \\
(0.035)\end{array}$ & & $\left|\begin{array}{l}0.124^{* * *} \\
(0.042)\end{array}\right|$ & & $\begin{array}{l}0.120^{* * *} \\
(0.043)\end{array}$ \\
\hline Asia & & $\begin{array}{l}-0.013 \\
(0.037)\end{array}$ & & $\begin{array}{l}-0.029 \\
(0.037)\end{array}$ & & $\mid \begin{array}{l}-0.073 \quad * \\
(0.038)\end{array}$ & & $\mid \begin{array}{l}-0.101 \quad * * * \\
(0.037)\end{array}$ & & $\begin{array}{c}0.038 \\
(0.041)\end{array}$ & & $\begin{array}{c}0.034 \\
(0.040)\end{array}$ \\
\hline Oceania & & $\begin{array}{c}0.018 \\
(0.041)\end{array}$ & & $\begin{array}{l}-0.006 \\
(0.046)\end{array}$ & & $\begin{array}{l}-0.035 \\
(0.042)\end{array}$ & & $\begin{array}{l}-0.070 \\
(0.048)\end{array}$ & & $\begin{array}{c}0.075 \\
(0.047)\end{array}$ & & $\begin{array}{c}0.065 \\
(0.051)\end{array}$ \\
\hline Sub-Saharan Africa & & $\left|\begin{array}{l}0.0911^{* * *} \\
(0.034)\end{array}\right|$ & & $\begin{array}{l}0.070 \quad * * \\
(0.033)\end{array}$ & & \begin{tabular}{|c}
0.029 \\
$(0.035)$
\end{tabular} & & $\begin{array}{l}-0.002 \\
(0.033)\end{array}$ & & $\mid \begin{array}{l}0.140 * * * \\
(0.037)\end{array}$ & & $\begin{array}{l}0.1333^{* * *} \\
(0.036)\end{array}$ \\
\hline Middle East/North Africa & & $\begin{array}{l}-0.042 \\
(0.034)\end{array}$ & & $\begin{array}{l}-0.087 \quad * * \\
(0.039)\end{array}$ & & $\begin{array}{l}-0.1055^{* * *} \\
(0.037)\end{array}$ & & $\left|\begin{array}{ll}-0.160 & * * * \\
(0.042)\end{array}\right|$ & & $\begin{array}{l}0.006 \\
(0.036)\end{array}$ & & $\begin{array}{l}-0.025 \\
(0.039)\end{array}$ \\
\hline North America & & $\begin{array}{c}0.073 \\
(0.062)\end{array}$ & & $\begin{array}{c}0.047 \\
(0.047)\end{array}$ & & \begin{tabular}{|c}
0.017 \\
$(0.063)$
\end{tabular} & & $\begin{array}{l}-0.019 \\
(0.050)\end{array}$ & & $\begin{array}{l}0.1288^{*} \\
(0.066)\end{array}$ & & $\begin{array}{l}0.116 \quad * * \\
(0.054)\end{array}$ \\
\hline Latin America & & $\begin{array}{c}0.017 \\
(0.029)\end{array}$ & & $\begin{array}{c}0.021 \\
(0.030)\end{array}$ & & \begin{tabular}{|l}
-0.039 \\
$(0.030)$
\end{tabular} & & $\begin{array}{l}-0.049 \\
(0.030)\end{array}$ & & $\mid \begin{array}{l}0.072 * * \\
(0.035)\end{array}$ & & $\begin{array}{l}0.086 \text { ** } \\
(0.036)\end{array}$ \\
\hline Constant & $\begin{array}{l}0.176 * * * \\
(0.065) \\
\end{array}$ & $\begin{array}{c}0.018 \\
(0.105) \\
\end{array}$ & $\begin{array}{l}0.177^{* *} \\
(0.077) \\
\end{array}$ & $\begin{array}{l}-0.023 \\
(0.113) \\
\end{array}$ & $\begin{array}{l}0.187^{* * *} \\
(0.063) \\
\end{array}$ & \begin{tabular}{|c}
0.079 \\
$(0.102)$ \\
\end{tabular} & $\begin{array}{l}0.211^{* * *} \\
(0.072) \\
\end{array}$ & $\begin{array}{c}0.057 \\
(0.108) \\
\end{array}$ & $\begin{array}{l}0.1644^{* *} \\
(0.067)\end{array}$ & $\begin{array}{l}-0.031 \\
(0.102) \\
\end{array}$ & \begin{tabular}{|c}
$0.140 *$ \\
$(0.076)$ \\
\end{tabular} & $\begin{array}{l}-0.078 \\
(0.106) \\
\end{array}$ \\
\hline Number of Observations & 3038 & 3038 & 3011 & 3011 & 3038 & 3038 & 3011 & 3011 & 3038 & 3038 & 3011 & 3011 \\
\hline Number of Countries & 152 & 152 & 151 & 151 & 152 & 152 & 151 & 151 & 152 & 152 & 151 & 151 \\
\hline Within R-Square & 0.69 & 0.69 & 0.685 & 0.686 & 0.689 & 0.690 & 0.685 & 0.686 & 0.690 & 0.690 & 0.685 & 0.686 \\
\hline Between R-Square & 0.995 & 0.995 & 0.996 & 0.995 & 0.996 & 0.995 & 0.996 & 0.995 & 0.995 & 0.995 & 0.995 & 0.995 \\
\hline Overall R-Square & 0.956 & 0.956 & 0.956 & 0.956 & 0.956 & 0.957 & 0.956 & 0.956 & 0.956 & 0.957 & 0.956 & 0.956 \\
\hline
\end{tabular}

Two-tailed tests with robust standard errors in parentheses; ${ }^{* * *} p<.01,{ }^{* *} p<.05,{ }^{*} p<.1$ 


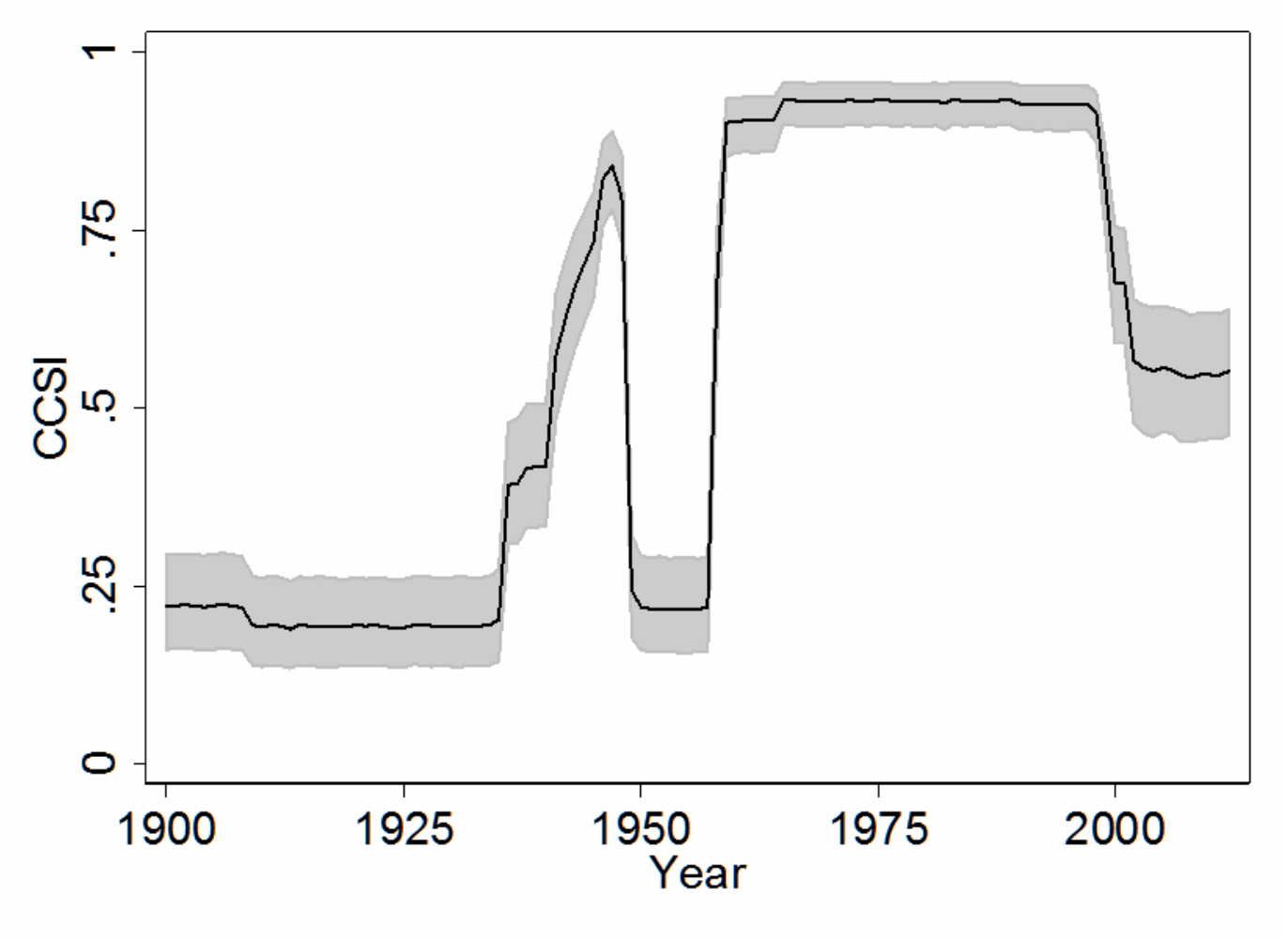

Figure 1: The Development of Civil Society in Venezuela, 1900-2012 


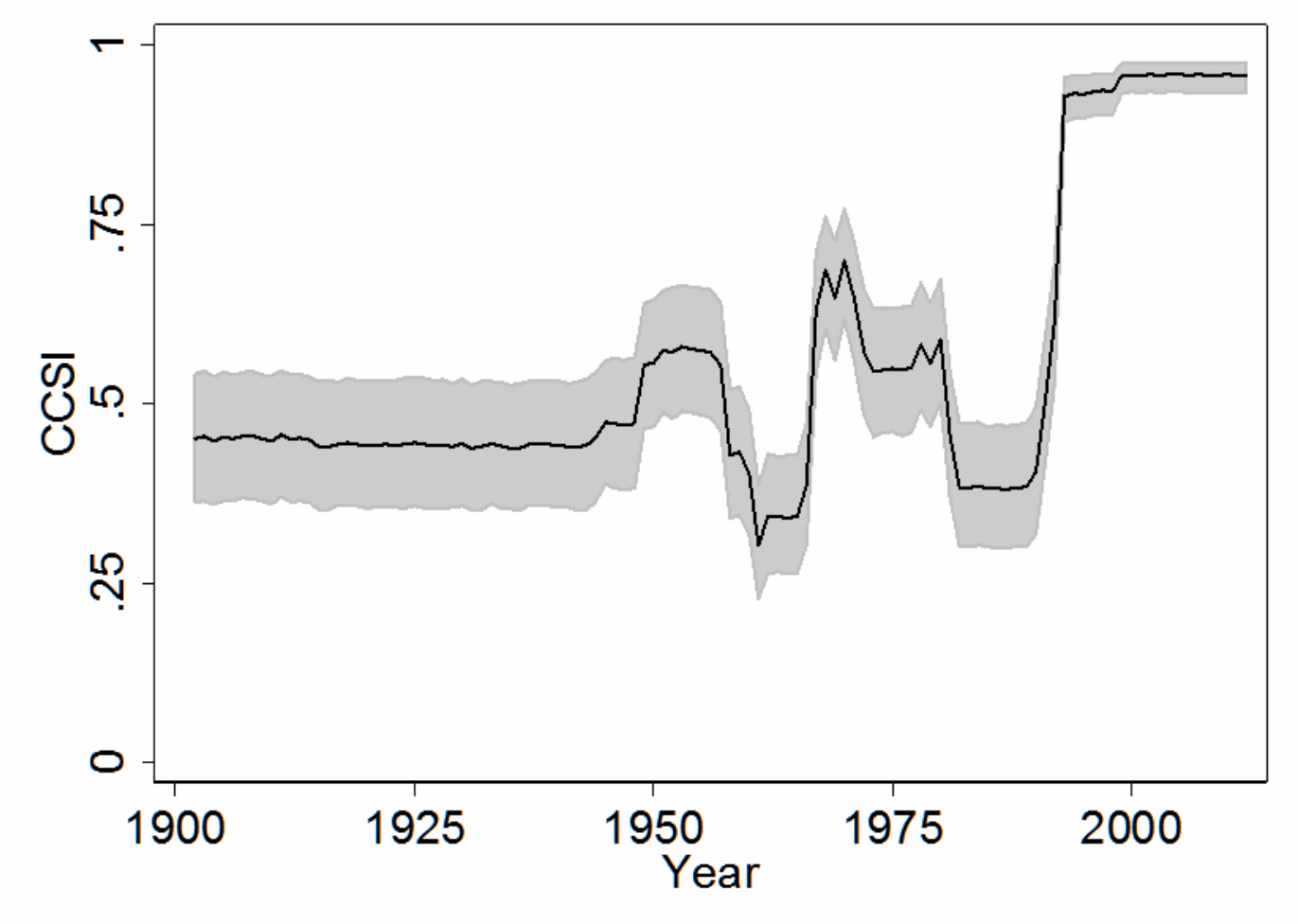

Figure 2: The Development of Civil Society in Ghana, 1900-2012 


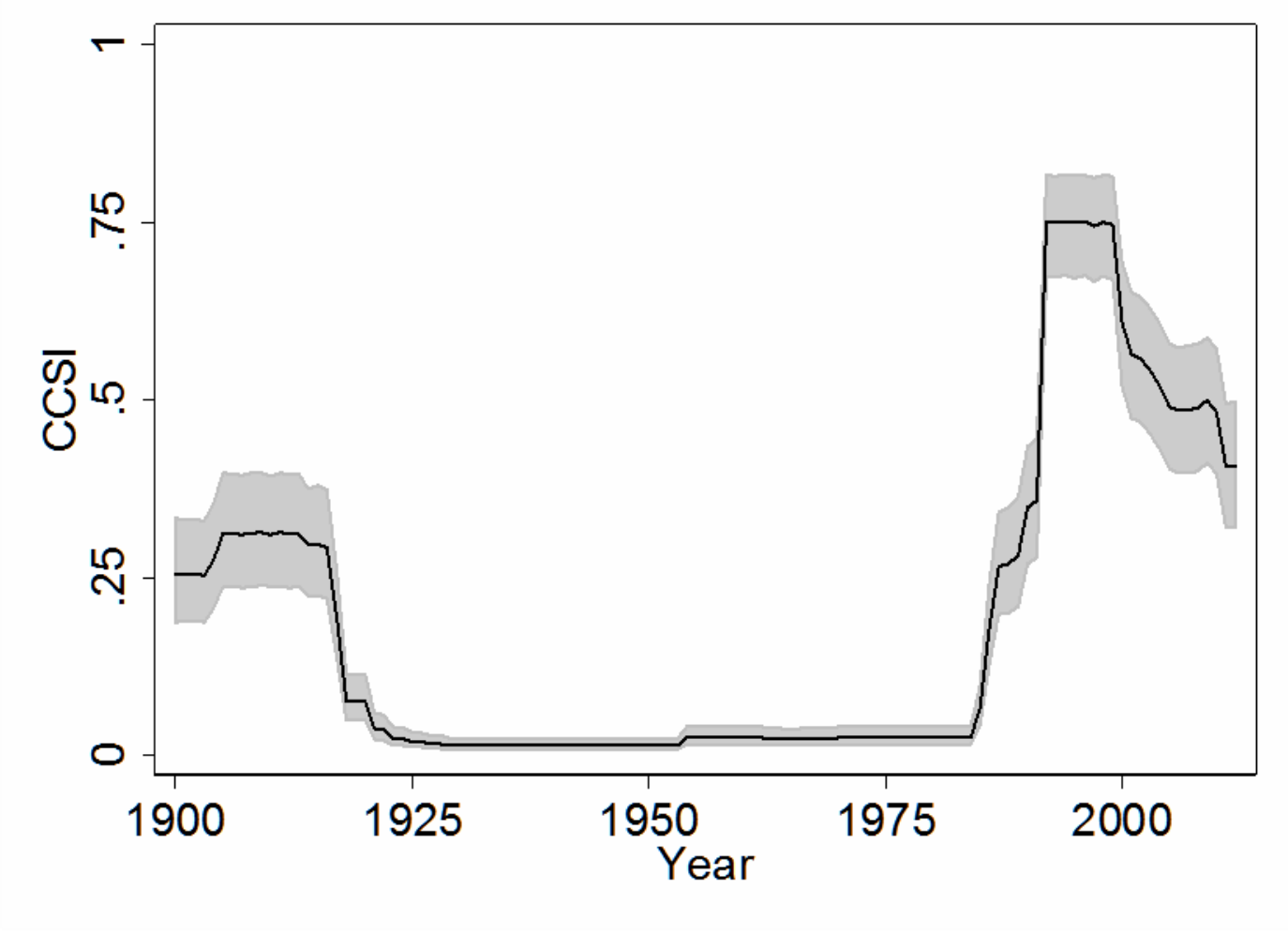

Figure 3: The Development of Civil Society in Russia, 1900-2012 


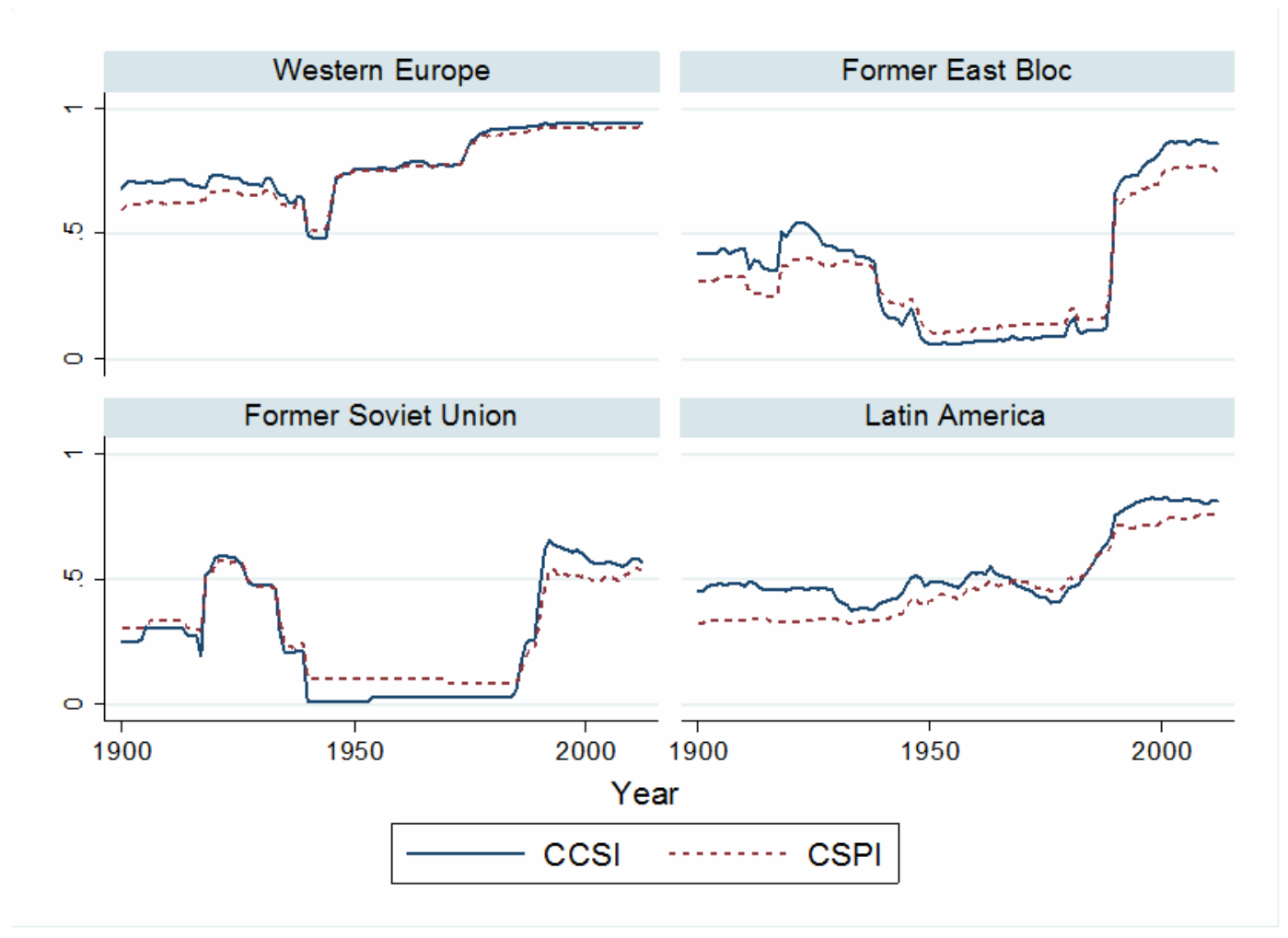

Figure 4: CCSI and CSPI over Time in Four Selected Regions 
Table 1: Relative Strength of Postcommunist Civil Societies Using Random Effects TSCS Regressions

\begin{tabular}{|c|c|c|c|c|c|c|c|c|}
\hline $\begin{array}{l}\text { Model } \\
\text { DV }\end{array}$ & $\begin{array}{c}1.1 \\
\mathrm{CCSI} \\
\end{array}$ & $\begin{array}{c}1.2 \\
\mathrm{CCSI} \\
\end{array}$ & $\begin{array}{c}1.3 \\
\mathrm{CCSI} \\
\end{array}$ & $\begin{array}{c}1.4 \\
\text { CCSI } \\
\end{array}$ & $\begin{array}{r}1.5 \\
\text { CSPI } \\
\end{array}$ & $\begin{array}{c}1.6 \\
\text { CSPI } \\
\end{array}$ & $\begin{array}{c}1.7 \\
\text { CSPI } \\
\end{array}$ & $\begin{array}{c}1.8 \\
\text { CSPI } \\
\end{array}$ \\
\hline Lagged DV & \begin{tabular}{|l}
$0.876^{* * *}$ \\
$(0.021)^{*}$
\end{tabular} & $\begin{array}{l}0.854^{* * *} \\
(0.024)^{*}\end{array}$ & \begin{tabular}{|l}
0.946 \\
$(0.011)$
\end{tabular} & \begin{tabular}{|l|}
$0.9277^{* * *}$ \\
$(0.015)$
\end{tabular} & \begin{tabular}{|l|}
$0.917^{* * *}$ \\
$(0.014)^{*}$
\end{tabular} & \begin{tabular}{|l|}
$0.898^{* * *}$ \\
$(0.016)^{*}$
\end{tabular} & \begin{tabular}{|l|}
$0.953^{* * *}$ \\
$(0.009)$
\end{tabular} & $\begin{array}{l}0.938^{* * *} \\
(0.011)\end{array}$ \\
\hline Logged GDP/capita (Divided by 1000) & $\begin{array}{l}-9.141^{* * *} \\
(1.946)\end{array}$ & $\begin{array}{l}-1.948 \\
(2.850)\end{array}$ & $\begin{array}{l}-2.313 \\
(1.876)\end{array}$ & $\begin{array}{c}3.766 \\
(2.918)\end{array}$ & $\mid \begin{array}{l}-5.9444^{* * *} \\
(1.345)\end{array}$ & $\begin{array}{l}-1.414 \\
(2.004)\end{array}$ & $\begin{array}{l}-2.488 * \\
(1.393)\end{array}$ & $\begin{array}{c}2.366 \\
(2.075)\end{array}$ \\
\hline Clean Election Index & $\left|\begin{array}{l}0.081^{* * *} \\
(0.015)\end{array}\right|$ & $\mid \begin{array}{l}0.084^{* * *} \\
(0.015)\end{array}$ & & & $\left|\begin{array}{c}0.046^{* * *} \\
(0.009)\end{array}\right|$ & $\mid \begin{array}{l}0.049^{* * *} \\
(0.010)\end{array}$ & & \\
\hline Decades of Democracy & & & $\begin{array}{c}0.001 \\
(0.001)\end{array}$ & $\begin{array}{c}0.000 \\
(0.001)\end{array}$ & & & $\mid \begin{array}{l}0.001 \quad * * \\
(0.000)\end{array}$ & $\begin{array}{c}0.000 \\
(0.000)\end{array}$ \\
\hline Regions & & & & & & & & \\
\hline Postcommunist Eurasia & $\begin{array}{c}0.008 \\
(0.006)\end{array}$ & & $\begin{array}{c}0.010 * \\
(0.006)\end{array}$ & & $\begin{array}{l}-0.002 \\
(0.003)\end{array}$ & & $\begin{array}{c}0.002 \\
(0.004)\end{array}$ & \\
\hline Western Europe & & $\begin{array}{l}-0.009 * \\
(0.005)\end{array}$ & & $\begin{array}{l}-0.004 \\
(0.006)\end{array}$ & & $\begin{array}{c}0.005 \\
(0.004)\end{array}$ & & $\begin{array}{c}0.003 \\
(0.004)\end{array}$ \\
\hline Asia & & $\begin{array}{l}-0.018 \quad * * \\
(0.009)\end{array}$ & & $\begin{array}{l}-0.016 \quad * * \\
(0.008)\end{array}$ & & $\begin{array}{l}-0.002 \\
(0.006)\end{array}$ & & $\begin{array}{l}-0.005 \\
(0.005)\end{array}$ \\
\hline Oceania & & $\begin{array}{l}-0.013 \quad * * \\
(0.005)\end{array}$ & & $\begin{array}{l}-0.007 \\
(0.007)\end{array}$ & & $\begin{array}{c}0.003 \\
(0.004)\end{array}$ & & $\begin{array}{c}0.000 \\
(0.005)\end{array}$ \\
\hline Sub-Saharan Africa & & $\begin{array}{l}0.012 \\
(0.009)\end{array}$ & & $\begin{array}{c}0.004 \\
(0.008)\end{array}$ & & $\begin{array}{l}0.017 \quad 7^{* * *} \\
(0.006)\end{array}$ & & $\begin{array}{c}0.010 * \\
(0.006)\end{array}$ \\
\hline Middle East/North Africa & & $\mid \begin{array}{ll}-0.030 & * * * \\
(0.010) & \end{array}$ & & $\begin{array}{l}-0.032 \\
(0.010)\end{array}$ & & $\begin{array}{l}-0.011 * \\
(0.006)\end{array}$ & & $\begin{array}{l}-0.0188^{* * *} \\
(0.006)\end{array}$ \\
\hline North America & & $\begin{array}{l}-0.010 \\
(0.007)\end{array}$ & & $\begin{array}{l}-0.006 \\
(0.007)\end{array}$ & & $\begin{array}{c}0.007 \\
(0.005)\end{array}$ & & $\begin{array}{c}0.002 \\
(0.004)\end{array}$ \\
\hline Latin America & & $\begin{array}{l}-0.006 \\
(0.008)\end{array}$ & & $\begin{array}{l}-0.002 \\
(0.007)\end{array}$ & & $\begin{array}{c}0.001 \\
(0.005)\end{array}$ & & $\begin{array}{c}0.002 \\
(0.005)\end{array}$ \\
\hline Constant & \begin{tabular}{|l}
$0.125^{* * *}$ \\
$(0.019)$ \\
\end{tabular} & $\begin{array}{l}0.103 \quad * * * \\
(0.026)\end{array}$ & \begin{tabular}{|c|}
$0.064^{* * *}$ \\
$(0.014)$ \\
\end{tabular} & $\begin{array}{c}0.035 \\
(0.023) \\
\end{array}$ & \begin{tabular}{|l|}
$0.088^{* * *}$ \\
$(0.013)^{*}$ \\
\end{tabular} & \begin{tabular}{|c|}
$0.056^{* * *}$ \\
$(0.018)^{*}$ \\
\end{tabular} & \begin{tabular}{|c|}
$0.058^{* * *}$ \\
$(0.011)$ \\
\end{tabular} & $\begin{array}{c}0.029 \\
(0.018) \\
\end{array}$ \\
\hline Number of Observations & 3044 & 3044 & 3016 & 3016 & 3038 & 3038 & 3011 & 3011 \\
\hline Number of Countries & 152 & 152 & 151 & 151 & 152 & 152 & 151 & 151 \\
\hline Within R-Square & 0.684 & 0.685 & 0.672 & 0.672 & 0.724 & 0.724 & 0.714 & 0.715 \\
\hline Between R-Square & 0.994 & 0.993 & 0.997 & 0.996 & 0.997 & 0.996 & 0.997 & 0.997 \\
\hline Overall R-Square & 0.942 & 0.944 & 0.942 & 0.943 & 0.956 & 0.957 & 0.955 & 0.956 \\
\hline
\end{tabular}

Two-tailed tests with robust standard errors in parentheses; ${ }^{* * *} p<.01,{ }^{* *} p<.05,{ }^{*} p<.1$ 
Table 2: Relative Strength of Former East Bloc Civil Societies Using Random Effects TSCS Regressions

\begin{tabular}{|c|c|c|c|c|c|c|c|c|}
\hline $\begin{array}{l}\text { Model } \\
\text { DV }\end{array}$ & $\begin{array}{c}2.1 \\
\text { CCSI }\end{array}$ & $\begin{array}{c}2.2 \\
\mathrm{CCSI}\end{array}$ & $\begin{array}{c}2.3 \\
\mathrm{CCSI}\end{array}$ & $\begin{array}{c}2.4 \\
\mathrm{CCSI}\end{array}$ & $\begin{array}{c}2.5 \\
\text { CSPI }\end{array}$ & $\begin{array}{c}2.6 \\
\text { CSPI }\end{array}$ & $\begin{array}{c}2.7 \\
\text { CSPI }\end{array}$ & $\begin{array}{c}2.8 \\
\text { CSPI }\end{array}$ \\
\hline Lagged DV & \begin{tabular}{|l|}
$0.887^{* * *}$ \\
$(0.020)^{*}$
\end{tabular} & \begin{tabular}{|c|}
$0.8633^{* * *}$ \\
$(0.024)^{*}$
\end{tabular} & \begin{tabular}{|l|}
$0.941^{* * *}$ \\
$(0.012)$
\end{tabular} & \begin{tabular}{|l|}
$0.921^{* * *}$ \\
$(0.015)^{2}$
\end{tabular} & $\begin{array}{l}0.922^{* * *} \\
(0.013)\end{array}$ & \begin{tabular}{|l|}
$0.899^{* * *}$ \\
$(0.016)$
\end{tabular} & \begin{tabular}{|l|}
$0.950^{* * *}$ \\
$(0.009)$
\end{tabular} & $\begin{array}{l}0.9311^{* * *} \\
(0.012)\end{array}$ \\
\hline Logged GDP/capita (Divided by 1000) & $\begin{array}{l}-8.723^{* * *} \\
(1.844)^{*}\end{array}$ & $\begin{array}{l}-1.813 \\
(2.652)\end{array}$ & $\begin{array}{l}-2.760 \\
(1.894)\end{array}$ & $\begin{array}{c}3.908 \\
(2.835)\end{array}$ & $\begin{array}{l}-6.060^{* * *} \\
(1.292)^{*}\end{array}$ & \begin{tabular}{|l}
-1.157 \\
$(1.857)$
\end{tabular} & $\begin{array}{l}-3.391^{* * *} \\
(1.283)\end{array}$ & $\begin{array}{c}2.503 \\
(1.955)\end{array}$ \\
\hline Clean Election Index & $\begin{array}{l}0.072^{* * *} \\
(0.014)\end{array}$ & $\begin{array}{l}0.0744^{* * *} \\
(0.015)\end{array}$ & & & $\begin{array}{l}0.042^{* * *} \\
(0.009)\end{array}$ & $\mid \begin{array}{l}0.045^{* * *} \\
(0.009)\end{array}$ & & \\
\hline Decades of Democracy & & & $\begin{array}{c}0.001 \\
(0.001)\end{array}$ & $\begin{array}{c}0.000 \\
(0.001)\end{array}$ & & & $\begin{array}{l}0.0022^{* * *} \\
(0.000)\end{array}$ & $\begin{array}{c}0.000 \\
(0.000)\end{array}$ \\
\hline Regions & & & & & & & & \\
\hline Former East Bloc & $\begin{array}{l}0.023^{* * *} \\
(0.005)\end{array}$ & & $\begin{array}{l}0.028^{* * *} \\
(0.005)^{*}\end{array}$ & & $\begin{array}{l}0.010^{* * *} \\
(0.003)\end{array}$ & & $\begin{array}{l}0.017^{* * *} \\
(0.004)^{* *}\end{array}$ & \\
\hline Former Soviet Union & & $\mid \begin{array}{ll}-0.029 & * * * \\
(0.010) & \end{array}$ & & $\begin{array}{l}-0.036 \quad * * * \\
(0.010)\end{array}$ & & \begin{tabular}{|l}
$-0.022^{* * *}$ \\
$(0.006)$
\end{tabular} & & $\begin{array}{l}-0.028^{* * *} \\
(0.006)\end{array}$ \\
\hline Western Europe & & $\mid \begin{array}{ll}-0.024 & * * * \\
(0.006) & \end{array}$ & & $\begin{array}{l}-0.021 \\
(0.006)\end{array}$ & & $\begin{array}{l}-0.006 \\
(0.004)\end{array}$ & & $\begin{array}{l}-0.010^{* *} \\
(0.005)\end{array}$ \\
\hline Asia & & $\mid \begin{array}{ll}-0.034 & * * * \\
(0.008) & \end{array}$ & & $\begin{array}{l}-0.036 \quad * * * \\
(0.007)\end{array}$ & & $\begin{array}{l}-0.015^{* * *} \\
(0.006)\end{array}$ & & $\begin{array}{l}-0.0200^{* * *} \\
(0.006)\end{array}$ \\
\hline Oceania & & $\mid \begin{array}{ll}-0.027 & * * * \\
(0.006) & \end{array}$ & & $\mid \begin{array}{l}-0.024 \\
(0.007)\end{array}$ & & $\begin{array}{l}-0.0088^{* *} \\
(0.004)\end{array}$ & & $\begin{array}{l}-0.0133^{* *} \\
(0.005)\end{array}$ \\
\hline Sub-Saharan Africa & & $\begin{array}{l}-0.005 \\
(0.008)\end{array}$ & & $\begin{array}{l}-0.015 \\
(0.007)\end{array}$ & & $\begin{array}{l}0.005 \\
(0.006)\end{array}$ & & $\begin{array}{l}-0.004 \\
(0.005)\end{array}$ \\
\hline Middle East/North Africa & & $\mid \begin{array}{ll}-0.045 & * * * \\
(0.010) & \end{array}$ & & $\begin{array}{l}-0.053 \\
(0.010)\end{array}$ & & $\begin{array}{l}-0.023^{* * *} \\
(0.006)\end{array}$ & & $\begin{array}{l}-0.034^{* * *} \\
(0.007)\end{array}$ \\
\hline North America & & $\mid \begin{array}{ll}-0.025 & * * * \\
(0.007) & \end{array}$ & & $\mid \begin{array}{ll}-0.024 & * * * \\
(0.006) & \end{array}$ & & $\begin{array}{l}-0.005 \\
(0.005)\end{array}$ & & $\begin{array}{l}-0.011^{* *} \\
(0.005)\end{array}$ \\
\hline Latin America & & $\begin{array}{ll}-0.021 & * * * \\
(0.007) & \end{array}$ & & $\mid \begin{array}{ll}-0.020 & * * * \\
(0.006) & \end{array}$ & & $\begin{array}{l}-0.010 * * \\
(0.005)\end{array}$ & & $\begin{array}{l}-0.012^{* *} \\
(0.005)\end{array}$ \\
\hline Constant & \begin{tabular}{|l}
0.119 \\
$(0.018)$
\end{tabular} & \begin{tabular}{|l|}
$0.099^{* * *}$ \\
$(0.023)^{*}$
\end{tabular} & \begin{tabular}{|l}
$0.0699^{* * *}$ \\
$(0.014)^{*}$
\end{tabular} & $\begin{array}{|ll|}0.057 & * * * \\
(0.022) & \\
\end{array}$ & \begin{tabular}{|l}
$0.0866^{* * *}$ \\
$(0.012)$
\end{tabular} & \begin{tabular}{|l|}
$0.068^{* * *}$ \\
$(0.017)^{*}$
\end{tabular} & \begin{tabular}{|l}
$0.066^{* * *}$ \\
$(0.011)$
\end{tabular} & $\begin{array}{l}0.046^{* * *} \\
(0.017)\end{array}$ \\
\hline Number of Obs & 3044 & 3044 & 3016 & 3016 & 3038 & 3038 & 3011 & 3011 \\
\hline Number of Countries & 152 & 152 & 151 & 151 & 152 & 152 & 151 & 151 \\
\hline Within R-Square & 0.683 & 0.684 & 0.672 & 0.672 & 0.723 & 0.724 & 0.714 & 0.715 \\
\hline Between R-Square & 0.995 & 0.994 & 0.997 & 0.996 & 0.997 & 0.997 & 0.998 & 0.997 \\
\hline Overall R-Square & 0.943 & 0.944 & 0.942 & 0.943 & 0.956 & 0.957 & 0.956 & 0.956 \\
\hline
\end{tabular}

Two-tailed tests with robust standard errors in parentheses; ${ }^{* * *} p<.01,{ }^{* *} p<.05,{ }^{*} p<.1$ 
Table 3: Relative Strength of Former Soviet Union Civil Societies Using Random Effects TSCS Regressions

\begin{tabular}{|c|c|c|c|c|c|c|c|c|}
\hline $\begin{array}{l}\text { Model } \\
\text { DV }\end{array}$ & $\begin{array}{c}3.1 \\
\text { CCSI }\end{array}$ & $\begin{array}{c}3.2 \\
\text { CCSI }\end{array}$ & $\begin{array}{c}3.3 \\
\text { CCSI }\end{array}$ & $\begin{array}{c}3.4 \\
\text { CCSI }\end{array}$ & $\begin{array}{c}3.5 \\
\text { CSPI }\end{array}$ & $\begin{array}{c}3.6 \\
\text { CSPI }\end{array}$ & $\begin{array}{c}3.7 \\
\text { CSPI }\end{array}$ & $\begin{array}{c}3.8 \\
\text { CSPI }\end{array}$ \\
\hline Lagged DV & $\begin{array}{l}0.864^{* * *} \\
(0.022)\end{array}$ & $\begin{array}{l}0.8633^{* * *} \\
(0.024)\end{array}$ & $\begin{array}{l}0.9455^{* * *} \\
(0.011)\end{array}$ & $\left|\begin{array}{l}0.921 \\
(0.015)\end{array}{ }^{* * *}\right|$ & $\begin{array}{l}0.913^{* * *} \\
(0.014)\end{array}$ & $\begin{array}{l}0.899^{* * *} \\
(0.016)\end{array}$ & $\mid \begin{array}{l}0.9511^{* * *} \\
(0.009)\end{array}$ & $\begin{array}{l}0.9311^{* * *} \\
(0.012)\end{array}$ \\
\hline Logged GDP/capita (Divided by 1000 ) & $\begin{array}{l}-8.280^{* * *} \\
(2.074)^{*}\end{array}$ & $\begin{array}{l}-1.813 \\
(2.652)\end{array}$ & $\begin{array}{l}0.090 \\
(1.958)\end{array}$ & $\begin{array}{c}3.908 \\
(2.835)\end{array}$ & $\begin{array}{l}-5.455^{* * *} \\
(1.351)^{*}\end{array}$ & $\begin{array}{l}-1.157 \\
(1.857)\end{array}$ & $\begin{array}{l}-1.167 \\
(1.352)\end{array}$ & $\begin{array}{l}2.503 \\
(1.955)\end{array}$ \\
\hline Clean Election Index & $\begin{array}{l}0.085^{* * *} \\
(0.016)\end{array}$ & $\begin{array}{l}0.074^{* * *} \\
(0.015)\end{array}$ & & & $\begin{array}{l}0.045^{* * *} \\
(0.009)\end{array}$ & $\begin{array}{l}0.045^{* * *} \\
(0.009)\end{array}$ & & \\
\hline Decades of Democracy & & & $\begin{array}{c}0.000 \\
(0.001)\end{array}$ & $\begin{array}{c}0.000 \\
(0.001)\end{array}$ & & & $\begin{array}{c}0.001 \\
(0.000)\end{array}$ & $\begin{array}{l}0.000 \\
(0.000)\end{array}$ \\
\hline Regions & & & & & & & & \\
\hline Former Soviet Union & $\begin{array}{l}-0.007 \\
(0.009)\end{array}$ & & $\begin{array}{l}-0.009 \\
(0.008)\end{array}$ & & $\begin{array}{l}-0.013^{* * *} \\
(0.004)\end{array}$ & & $\begin{array}{l}-0.0122^{* *} \\
(0.005)\end{array}$ & \\
\hline Former East Bloc & & $\begin{array}{l}0.0299^{* * *} \\
(0.010)\end{array}$ & & $\begin{array}{l}0.036 \quad * * * \\
(0.010)\end{array}$ & & $\begin{array}{l}0.022^{* * *} \\
(0.006)\end{array}$ & & $\begin{array}{l}0.028 \\
(0.006)\end{array}$ \\
\hline Western Europe & & $\begin{array}{c}0.006 \\
(0.009)\end{array}$ & & $\begin{array}{c}0.015 \\
(0.009)\end{array}$ & & $\begin{array}{l}0.016^{* * *} \\
(0.006)\end{array}$ & & $\begin{array}{l}0.017 \quad{ }^{* * *} \\
(0.006)\end{array}$ \\
\hline Asia & & $\begin{array}{l}-0.004 \\
(0.010)\end{array}$ & & $\begin{array}{l}0.000 \\
(0.010)\end{array}$ & & $\begin{array}{r}0.008 \\
(0.006)\end{array}$ & & $\begin{array}{l}0.007 \\
(0.006)\end{array}$ \\
\hline Oceania & & $\begin{array}{c}0.002 \\
(0.009)\end{array}$ & & $\begin{array}{c}0.012 \\
(0.010)\end{array}$ & & $\begin{array}{l}0.015^{* * *} \\
(0.005)^{* *}\end{array}$ & & $\begin{array}{l}0.015^{* *} \\
(0.007)\end{array}$ \\
\hline Sub-Saharan Africa & & $\left(\begin{array}{c}0.024 \\
(0.010)\end{array}\right.$ & & $\begin{array}{l}0.021^{* *} \\
(0.010)\end{array}$ & & $\mid \begin{array}{ll}0.027 & * * * \\
(0.006)\end{array}$ & & $\begin{array}{l}0.024^{* * *} \\
(0.006)\end{array}$ \\
\hline Middle East/North Africa & & $\begin{array}{l}-0.015 \\
(0.011)\end{array}$ & & $\begin{array}{l}-0.017 \\
(0.011)\end{array}$ & & $\begin{array}{l}-0.001 \\
(0.006)\end{array}$ & & $\begin{array}{l}-0.006 \\
(0.006)\end{array}$ \\
\hline North America & & $\begin{array}{c}0.005 \\
(0.010)\end{array}$ & & $\begin{array}{c}0.012 \\
(0.009)\end{array}$ & & $\begin{array}{l}0.018^{* * *} \\
(0.006)\end{array}$ & & $\begin{array}{l}0.017^{* * *} \\
(0.006)\end{array}$ \\
\hline Latin America & & $\begin{array}{c}0.009 \\
(0.010)\end{array}$ & & $\begin{array}{r}0.016 \\
(0.010)\end{array}$ & & $\begin{array}{l}0.012 \quad * * \\
(0.006)\end{array}$ & & $\begin{array}{l}0.0166^{* *} \\
(0.006)\end{array}$ \\
\hline Constant & \begin{tabular}{|l}
0.126 \\
$(0.020)$ \\
\end{tabular} & $\begin{array}{l}0.070^{* * *} \\
(0.024) \\
\end{array}$ & \begin{tabular}{|c|}
$0.049^{* * *}$ \\
$(0.013)^{*}$ \\
\end{tabular} & $\begin{array}{c}0.022 \\
(0.021) \\
\end{array}$ & \begin{tabular}{|l|}
$0.087^{* * *}$ \\
$(0.013)$
\end{tabular} & \begin{tabular}{|l|}
$0.046^{* * *}$ \\
$(0.016)$ \\
\end{tabular} & \begin{tabular}{|l|}
$0.051^{* * *}$ \\
$(0.010)$ \\
\end{tabular} & $\begin{array}{c}0.019 \\
(0.016) \\
\end{array}$ \\
\hline Number of $\mathrm{O}$ & 3044 & 3044 & 3016 & 3016 & 3038 & 3038 & 3011 & 3011 \\
\hline Number of Countries & 152 & 152 & 151 & 151 & 152 & 152 & 151 & 151 \\
\hline Within R-Square & 0.685 & 0.684 & 0.672 & 0.672 & 0.724 & 0.724 & 0.714 & 0.715 \\
\hline Between R-Square & 0.993 & 0.994 & 0.997 & 0.996 & 0.997 & 0.997 & 0.997 & 0.997 \\
\hline Overall R-Square & 0.942 & 0.944 & 0.942 & 0.943 & 0.956 & 0.957 & 0.955 & 0.956 \\
\hline
\end{tabular}

Two-tailed tests with robust standard errors in parentheses; ${ }^{* * *} \mathrm{p}<.01,{ }^{* *} \mathrm{p}<.05,{ }^{*} \mathrm{p}<.1$ 